\title{
Review
}

\section{SALL Proteins; Common and Antagonistic Roles in Cancer}

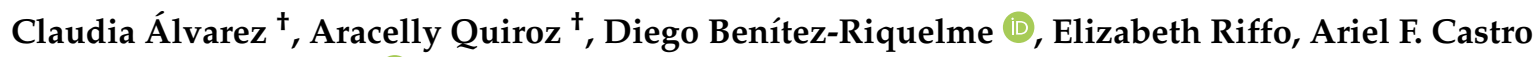 \\ and Roxana Pincheira *(D)
}

check for updates

Citation: Álvarez, C.; Quiroz, A.; Benítez-Riquelme, D.; Riffo, E.; Castro, A.F.; Pincheira, R. SALL Proteins; Common and Antagonistic Roles in Cancer. Cancers 2021, 13, 6292. https://doi.org/10.3390/ cancers 13246292

Academic Editor: Sanjay Gupta

Received: 1 November 2021

Accepted: 9 December 2021

Published: 15 December 2021

Publisher's Note: MDPI stays neutral with regard to jurisdictional claims in published maps and institutional affiliations.

Copyright: (C) 2021 by the authors. Licensee MDPI, Basel, Switzerland. This article is an open access article distributed under the terms and conditions of the Creative Commons Attribution (CC BY) license (https:// creativecommons.org/licenses/by/ $4.0 /)$.
Departamento de Bioquímica y Biología Molecular, Facultad de Ciencias Biológicas, Universidad de Concepción, Concepción 3349001, Chile; clalvarez@udec.cl (C.Á.); aracellyquiroz@udec.cl (A.Q.); diegobenitez@udec.cl (D.B.-R.); elizriffo@udec.cl (E.R.); arcastro@udec.cl (A.F.C.)

* Correspondence: ropincheira@udec.cl; Tel.: +56-412-203-815

+ Equal contribution.

Simple Summary: Transcription factors play essential roles in regulating gene expression, impacting the cell phenotype and function, and in the response of cells to environmental conditions. Alterations in transcription factors, including gene amplification or deletion, point mutations, and expression changes, are implicated in carcinogenesis, cancer progression, metastases, and resistance to cancer treatments. Not surprisingly, transcription factor activity is altered in numerous cancers, representing a unique class of cancer drug targets. This review updates and integrates information on the SALL family of transcription factors, highlighting the synergistic and/or antagonistic functions they perform in various cancer types.

Abstract: SALL proteins are a family of four conserved $\mathrm{C} 2 \mathrm{H} 2$ zinc finger transcription factors that play critical roles in organogenesis during embryonic development. They regulate cell proliferation, survival, migration, and stemness; consequently, they are involved in various human genetic disorders and cancer. SALL4 is a well-recognized oncogene; however, SALL1-3 play dual roles depending on the cancer context and stage of the disease. Current reviews of SALLs have focused only on SALL2 or SALL4, lacking an integrated view of the SALL family members in cancer. Here, we update the recent advances of the SALL members in tumor development, cancer progression, and therapy, highlighting the synergistic and/or antagonistic functions they perform in similar cancer contexts. We identified common regulatory mechanisms, targets, and signaling pathways in breast, brain, liver, colon, blood, and HPV-related cancers. In addition, we discuss the potential of the SALL family members as cancer biomarkers and in the cancer cells' response to therapies. Understanding SALL proteins' function and relationship will open new cancer biology, clinical research, and therapy perspectives.

Keywords: SALL1; SALL2; SALL3; SALL4; cancer; epigenetic regulation; Wnt; PTEN; biomarker

\section{Introduction}

SALL proteins are transcription factors that belong to the Spalt-like (Sall) family, broadly conserved through evolution. They are present in nematodes, flies, planarians, bilaterians, and vertebrates. They were first identified in Drosophila melanogaster, which harbors two paralogs: spalt major (salm) and spalt-related (salr). Both proteins play a role in the homeotic specification of the embryonic termini, wing patterning, sensory organ development, and photoreceptors specification [1,2]. A recent study in bilaterians suggests an ancestral role of sall in neural development [3].

Vertebrate genomes harbor four paralogs, SALL1-SALL4, apparently originated by several duplication events of the spalt locus and evolved from one ancestor more closely related to Drosophila (salm ortholog) [2]. A phylogenetic analysis of SALL proteins indicates that SALL1 and SALL3 derived from one common ancestor, and SALL4 derived from a more distant one. SALL2 shares the least homology, being the most dissimilar 
member of the SALL family, especially in the C-terminal region [4]. They are characterized by multiple zinc finger domains throughout the protein, a glutamine-rich (poly-Q) region important for protein-protein interactions, and a conserved twelve-amino-acid domain at the $\mathrm{N}$-terminal region responsible for the repression activity of SALL proteins, mediated by an interaction with the Nucleosome Remodeling and Deacetylase (NuRD) complex [5] (Figure 1). The zinc finger domain 1 corresponds to the $\mathrm{C} 2 \mathrm{HC}$ class, and the rest of the domains (2-5) correspond to the $\mathrm{C} 2 \mathrm{H} 2$ zinc fingers arranged in pairs. The second finger from each pair contains a characteristic domain called Sal-box (FTTKGNLK), present in other zinc finger transcription factors such as Schurri and PRDII-BF1 [3]. The third zinc finger domain contains an associated finger also highly conserved among orthologs. The function of SALL proteins requires nuclear localization, likely depending on the zinc finger 1 [5] (Figure 1).
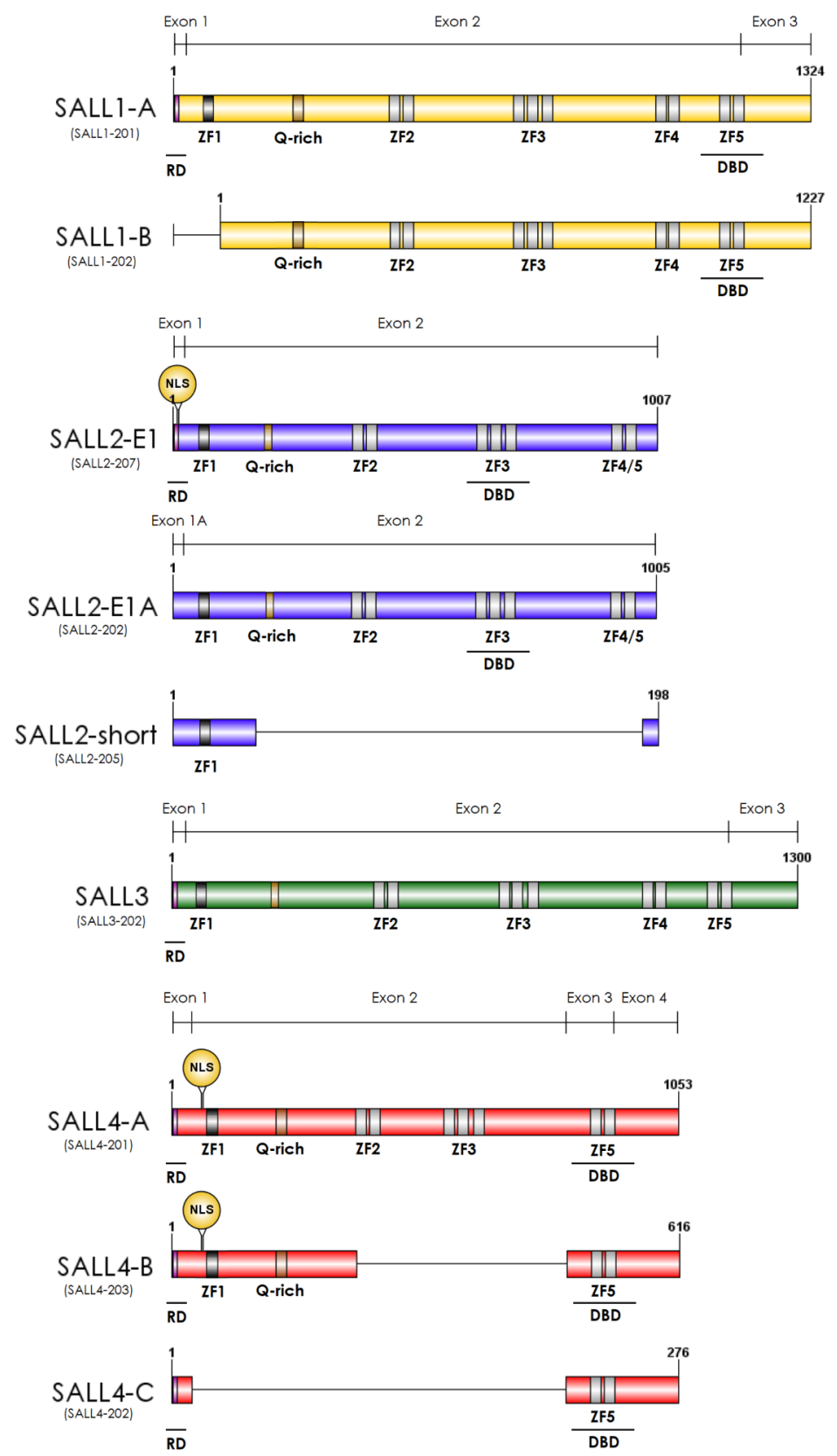

Figure 1. Schematic representation of the main SALL protein isoforms. The colors represent the different SALL proteins; yellow, blue, green, and red for SALL1, SALL2, SALL3, and SALL4, respectively. Dark grey rectangles at the N-terminal region represent the C2HC-type Zinc Finger Motif (ZF1). 
Light grey rectangles represent C2H2-type Zinc Finger Motifs 2-5 (ZF2-ZF5); all of them are in SALL1-A, SALL1-B, and SALL3. SALL4 lacks ZF4, and SALL2 has a motif that differs from the others, located between ZF4 and ZF5 (depicted as ZF4/5). The pink rectangle at the N-terminal region represents the conserved 12-amino-acid region that binds to the NuRD complex, named repression domain (RD). The RD is in SALL1A, SALL2 E1, SALL3, SALL4 A, B, and C. The yellow rectangle between ZF1 and ZF2 corresponds to the conserved Glutamine-rich (Q-rich) region. The circle at the described only for SALL2 N-terminal region shows the nuclear localization sequences (NLS) E1A, and SALL4 A and B. The ensembl transcript ID is under each isoform name in brackets. Exon representation is above each SALL protein, and the protein length is at the end of each isoform. ZF: Zinc Finger; Q-rich: Glutamine-rich; RD: Repression Domain; DBD: DNA Binding Domain; NLS: Nuclear Localization Sequence.

SALL proteins act as tumor suppressors, oncogenes, or have a dual function depending on the tissue, genetic context, epigenetic regulation, and specific SALL isoforms implicated, among others. SALL1, SALL2, and SALL4 cancer-related isoforms have been reported [6-10]. Considering that isoforms differ in structure and might have differential expressions and cellular location, they could be responsible for some of the different functions of SALL proteins in cancer (Figure 1).

Current reviews on SALL proteins' role in cancer are available; however, they are only focused on SALL4 or SALL2 [4,11-15], lacking an integrated view of the SALL family. Most cancer studies relate SALL4 to an oncogenic function and SALL1-3 to a tumor suppression role; still, there is evidence that SALL1 and SALL2 could play a dual role. Here, we will update information and integrate studies involving the SALL proteins in tumor development, progression, and cancer therapy, highlighting their synergistic and/or antagonistic functions in similar cancer types. We will also discuss their potential as cancer biomarkers and therapeutic targets. Understanding SALL proteins' function and how they behave in similar cellular contexts will open new perspectives in cancer biology, clinical research, and therapies.

\section{Essential Roles of SALL Genes during Development}

Vertebrate SALL proteins participate in the development of extremities and organs, including the brain, kidney, eye, and heart. Accordingly, SALL genes are implicated in human genetic disorders [1-5,16]. Mutations of SALL1 cause the Townes-Brocks syndrome (TBS), a rare autosomal malformation syndrome characterized by anal, renal, limb, and ear anomalies (Reviewed in [1,2]). Similarly, SALL4 mutations cause the Okihiro/Duane-radial ray syndrome (DRRS), an autosomal dominant condition characterized by upper-limb anomalies, ocular anomalies, and renal anomalies in some cases [17]. Meanwhile, SALL2 deficiency causes recessive ocular coloboma [18]. SALL3 deficiency is associated with ocular anomalies and facial dysmorphism of the human 18q deletion syndrome [19].

Functional studies using knockout mice confirmed the essential roles of Sall1, Sall3, and Sall4 during development. Loss of function of these genes results in perinatal or neonatal lethality due to organ alterations during embryonic development. The organ alterations include kidney agenesis or dysgenesis, abnormal cranial nerve morphology, and exencephaly [20-22]. Two Sall2 knockout (KO) models exist; the first Sall2KO model did not show an essential role for Sall2 in embryonic or kidney development [23]. However, the second Sall2KO model showed severe neural tube defects and defects in the optic fissure closure, similar to the phenotype of coloboma patients [18,24]. Differences between the phenotype of Sall2KO models might be related to the different genetic backgrounds of the mice strains used $[23,24]$. Sall2KO did not show spontaneous tumor formation [23], but when crossed with tumor-susceptible mice $p 53^{-/-}$, it exhibited significantly accelerated tumorigenesis, tumor progression, and mortality rate among Sall2 ${ }^{+/+} / p 53^{-/-}$mice. The Sall2 ${ }^{-/-}$or Sal2 ${ }^{-/+} / p 53^{-/-}$mice showed thymus T-cell lymphoma that metastasized to the liver, lung, kidney, marrow, peripheral blood, and central nervous system, 
while in most $\mathrm{Sall}^{+/+} / p 53^{-/-}$mice, the lymphoma was limited to the thymus and adjacent organs such as the lung [25]. Moreover, supporting a tumor suppressor function, the immortalized Sall2 ${ }^{-/}$MEFs showed an enhanced growth rate, foci formation, and anchorage-independent growth in comparison to the immortalized Sall2 ${ }^{+/+}$MEFs [26].

In development, common findings on SALL proteins include a direct interaction with chromatin remodeling complexes, such as the SWI/SNF or NuRD complexes, and an association with the canonical Wnt/ $\beta$-catenin pathway $[5,10,27-30]$. Particularly relevant for the SALLs function is their interaction with the NuRD complex. NuRD is involved in global transcriptional repression and the regulation of specific developmental processes [29,31]. SALLs interact with the NuRD complex through the conserved 12-amino-acid motif. This motif is not present in some SALL isoforms (Figure 1), suggesting that NuRD is essential in differentiating their function. However, there is a lack of studies addressing this issue. Most of the studies have focused on the functional relationship of NuRD with SALL1 or SALL4 in development and cancer. In kidney development and leukemogenesis, the function of SALL4 through the NuRD complex relies on the repression of PTEN and SALL1 [32]. In other contexts, the interaction between SALL4 and NuRD impacts different genes. SALL4 was involved in spermatogonial differentiation. SALL4/NuRD repressed the expression of the tumor suppressor genes Foxl1 and Dusp4, associating SALL4 function with the maintenance of undifferentiated spermatogonial activity and stem cell-driven regeneration [33]. However, in the context of pluripotent cell transcriptional programs, free SALL4 regulates transcription independently of NuRD [34].

The SALL1/NuRD complex is also involved in kidney development, inhibiting the premature differentiation of nephron progenitor cells. The disruption of SALL1/NuRD interaction in vivo resulted in the accelerated differentiation of nephron progenitors and bilateral renal hypoplasia [28]. In Xenopus embryos, SALL1 interaction with NuRD directly repressed Gbx2, a transcription factor for cell pluripotency and differentiation in the embryo [35]. Interestingly, SALL1 association with NuRD is disrupted by the protein kinase $C$ phosphorylation at serine 2 of the repression motif, suggesting that this kinase regulates the NuRD-dependent repression function of SALL1 [35]. SALL1 phosphorylation by PKC may also be involved in breast cancer [36]. SALL1/NuRD inhibited breast cancer cell growth, proliferation, and metastasis, and a phosphomimetic mutation of SALL1 impaired its tumor suppressor function. Whether Gbx2 is associated with the tumor suppressor function of SALL1 is currently unknown.

As with many genes that play essential roles in organogenesis during embryonic development, SALL genes are involved in cancer. Developmental pathways are crucial for the cellular processes required during embryonic stages, such as epithelial-mesenchymal transition (EMT), coordinated migration, and cell proliferation, which are also essential at different stages of tumor progression [37]. Increasing evidence shows an association of SALL proteins with these processes, which are discussed below.

\section{Common Cellular Functions and Targets of the SALL Proteins in Cancer}

The number of identified SALL proteins' target genes has increased in recent years. They are associated with diverse cellular events such as proliferation, cell death, migration, invasion, and stemness.

\subsection{Cell Proliferation}

Several studies have established the role of SALL proteins in cell proliferation, acting as oncogenes or tumor suppressors under different pathological contexts. For instance, ectopic SALL2 expression inhibited SKOV3 ovarian cancer cell proliferation by a mechanism that involves the positive transcriptional regulation of cell cycle inhibitors such as p21 and p16 [38,39]. Accordingly, SALL2 depletion increased A2780 ovarian carcinoma cell proliferation [40]. The loss of Sall2 in mouse embryonic fibroblasts (MEF) enhanced cell proliferation and showed faster postmitotic progression through the G1 and S phases. The mechanism is related to the transcriptional derepression of two SALL2 targets, cyclins D1 
and E1 [26]. On the contrary, SALL4 accelerated cell cycle progression in cervical, lung, and breast cancer cells, as well as in esophagus squamous cell carcinoma and glioma [41-45]. The opposite roles of SALL2 and SALL4 in cell proliferation agree with the regulation of c-MYC, a transcription factor involved in cell growth and cell cycle control. SALL2 directly binds to the nuclease hypersensitive element in the promoter of $c-M Y C$, repressing its expression [46]. However, SALL4 indirectly increases the levels of c-MYC by activating the Wnt pathway. SALL4 enhanced the proliferative capacity of HeLa and SiHa cervical cancer cells through the positive transcriptional regulation of CTNNB1 [41]. CTNNB1 encodes $\beta$-catenin, a transcriptional cofactor of TCF/LEF in the Wnt signaling pathway. Additionally, SALL4 is directly bound to $\beta$-catenin, which activates the Wnt pathway in AML (acute myeloid leukemia) [8]. In both studies, Wnt pathway activation by SALL4 increased c-MYC and cyclin D1, which are related to increased proliferation, survival, EMT, and metastasis $[8,41]$.

SALL1 is also associated with increased $\beta$-catenin expression in human primary AML samples, and the inhibition of SALL1 resulted in decreased cell proliferation and AML engraftment in NSG (NOD scid gamma) mice [9]. Interestingly, similar to SALL4, SALL1 interacts with $\beta$-catenin in human kidney BOSC23 cells derived from HEK293T cells [47], suggesting a common mechanism for Wnt pathway activation via the interaction of $\beta$-catenin with SALL1 and/or SALL4. However, in contrast to the AML context, SALL1 over-expression in MDA breast cancer cells inhibited tumor cell growth and proliferation. It promoted cell cycle arrest by increasing Cyclin A2, Cyclin B1, Cyclin E1, CDK2, and CDK4, which are essential for checkpoint regulation in the G1-S transition and S phases [36]. These findings suggest a dual role for SALL1 in cancer, depending on the cell context.

\subsection{Apoptosis and Cell Survival}

SALL proteins' target genes are also associated with the regulation of apoptosis, indicating that SALL2 and SALL4 play opposite roles in this process. Using chromatin immunoprecipitation followed by microarray hybridization in the human acute promyelocytic leukemia cell line NB4, Yang and collaborators validated the SALL4 upregulation of anti-apoptotic genes, such as Bmi-1, BCL2, DAD1, TEGT, BIRC7, and BIRC4, and the negative regulation of pro-apoptotic genes, such as TNF, TP53, PTEN, CARD9, CARD11, ATF3, and LTA. Moreover, the inhibition of SALL4 induced apoptosis in NB4 cells, increasing DNA fragmentation as well as caspase-3 and annexin V levels [48]. On the other hand, the apoptotic cell response to genotoxic stress and Trichostatin A (TSA) treatment required SALL2 [49-51]. In response to doxorubicin- and etoposide-induced genotoxic stress, SALL2 induced pro-apoptotic genes such as BAX and PMAIP1 (also known as NOXA) in human ovarian surface epithelial (HOSE) cells and MEFs. Particularly noteworthy is the pro-apoptotic role of SALL2, which was independent of p53 expression, suggesting the key role of SALL2 in the response of cancer cells to therapy in p53 inactive cancer contexts $[49,50]$.

\subsection{Cell Migration and Invasion}

Migratory and invasive cell capacities increase during tumor development, which are strongly associated with metastasis in advanced stages of cancer. There are several mechanisms by which tumor cells acquire these characteristics of malignancy. One of the central mechanisms is the inhibition of PTEN, a phosphatase that blocks the PI3K signaling pathway, inhibiting cell migration, proliferation, and survival [52]. SALL4 repressed PTEN expression through its interaction with the NuRD complex and favored the development of AML in mice [32]. In ICC-9810 cholangiocarcinoma cells, SALL4 inhibited migratory and invasive capacities through the repression of PTEN and the upregulation of Bmi-1 [53]. Similarly, SALL1 inhibition increased PTEN expression in AML cell lines and primary samples and downregulated mTOR, $\beta$-catenin, and NF-қB expression [9]. SALL1 is bound to the NuRD complex in breast cancer; thus, it is likely that SALL1 and SALL4 share a similar repressive mechanism for PTEN regulation. However, no changes in PTEN 
expression were detected in breast cancer cells with SALL1 over-expression, suggesting that the regulation of PTEN by SALL1 is tissue-specific [36].

Meanwhile, SALL2 induces PTEN expression. In breast cancer cells, SALL2 silencing activated the AKT/mTOR pathway via the downregulation of PTEN. The mechanism involves the positive regulation of PTEN through the direct binding of SALL2 to canonical GC-rich consensus elements in the PTEN promoter [54]. Although this study did not associate SALL2-dependent PTEN regulation with cell migration, previous studies demonstrated that SALL2 expression correlated with impaired cell migration in human ovarian and esophageal carcinoma cell lines [40,55]. Additionally, the CDH1 and VIM genes, involved in migration, invasion, and EMT, are common targets for SALL1 and SALL4 in breast cancer (discussed below).

\subsection{Stemmess}

Maintenance of stemness is another essential feature of the heterogeneous cell population within the tumor, increasing its complexity by conferring the ability to differentiate into many unrelated cell types.

The role of SALL proteins in stemness maintenance is relevant during embryo development and cell fate. For instance, SALL2 and SALL4 are necessary factors for the self-renewal of hematopoietic stem cells (HSC) [25,56,57]. Interestingly, several studies suggest that SALL1 and SALL4 act as stemness or differentiation factors, depending on the development stage and the cell type involved. SALL1 is required for the stem cell maintenance of kidney, heart, and spermatogonial progenitors [27,58-60]. However, SALL1 also participates in the heart and odontoblast lineage differentiation [59,61]. Similarly, SALL4 plays opposite roles in postnatal spermatogenesis and embryonic germ cells [62]. During spermatogonia differentiation, SALL4 sequesters Plzf, a factor required to maintain adult stemness. This interaction leads to the expression of the differentiation marker KIT and the repression of SALL1 [62]. SALL1 expression in the germline is specific for spermatogonia progenitor cells. It was proposed as one of the factors involved in spermatogonial stem cell self-renewal [58].

SALL4 was proposed as a crucial factor for maintaining pluripotency in embryonic stem cells (ESCs) by its direct interaction with the core master regulators SOX2 and OCT4 [63]. Recent research has revealed that SALL4 maintains the pluripotent state in ESCs by regulating a set of AT-rich genes that promote neuronal differentiation. Worthy of note here is that the AT-rich gene pull-down by SALL4 depends on the $\mathrm{C} 2 \mathrm{H} 2$ zinc-finger cluster 4 (ZFC4) domain, also found in SALL1 and SALL3, but not in SALL2 [64].

Interestingly, the putative tumor suppressor SALL2 was identified as one of the critical transcription factors necessary for maintaining the tumor propagating cells in glioblastoma. SALL2 interacted with SOX2, OCT4, and Nanog in this specific context, promoting stemness and aggressive behavior [65]. Similarly, SALL1 can interact with SOX2 and Nanog, but not with OCT4, and consequently induce an undifferentiated state. SALL1 also suppresses ectodermal and mesodermal differentiation. Meanwhile, SALL1 overexpression was found to inhibit the induction of gastrulation markers (T brachyury, Goosecoid, and Dkk1) and neuroectodermal markers (Otx2 and Hand1) [66]. Recently, SALL3 was identified as part of a small set of transcription factors, including SOX2 and SALL2, that interact with the Mediator complex in neural stem cells [67]. Altogether, these studies identified SOX2 as a common SALL protein partner, relevant for the maintenance of stemness.

\section{Common Regulatory Mechanisms for SALL Proteins in Cancer}

The regulation of SALL proteins is an open field of study and involves several different mechanisms for each family member. These include genetic alterations and specific transcriptional, posttranscriptional, and posttranslational regulation. However, a common regulatory mechanism for all family members relates to epigenetic modifications, including chromatin modifications and microRNAs (miRNAs). 
The loss of heterozygosity $(\mathrm{LOH})$ was reported in overlapping regions of SALL genes in several independent cancer studies and was associated with poor prognosis and metastatic recurrence. These regions include SALL1 (16q12.1) [68,69], SALL2 (14q11.1-12) [70-76], and SALL3 (18q23) [76-78]. On the other hand, chromosomal amplifications were found in the SALL4 region (20q13.2) [79-85].

Specific transcription factors regulate the expression of SALL genes. SALL2 is transcriptionally activated by AP4 and Sp1 [51,86] and repressed by WT1, p53, and FosL1 [87-89]. On the other hand, TCF/LEF, STAT3, and CDX1 are transcriptional activators of SALL4 [10,90,91] (Figure 2). Remarkably, SALL4 controls their expression and represses SALL1 and SALL3, thus regulating the stemness of ES cells [63]. In murine transgenic models, SALL4 represses SALL1 and PTEN through the NuRD repressor complex, leading to pathologies such as cystic kidney and myeloid leukemia, respectively [32].

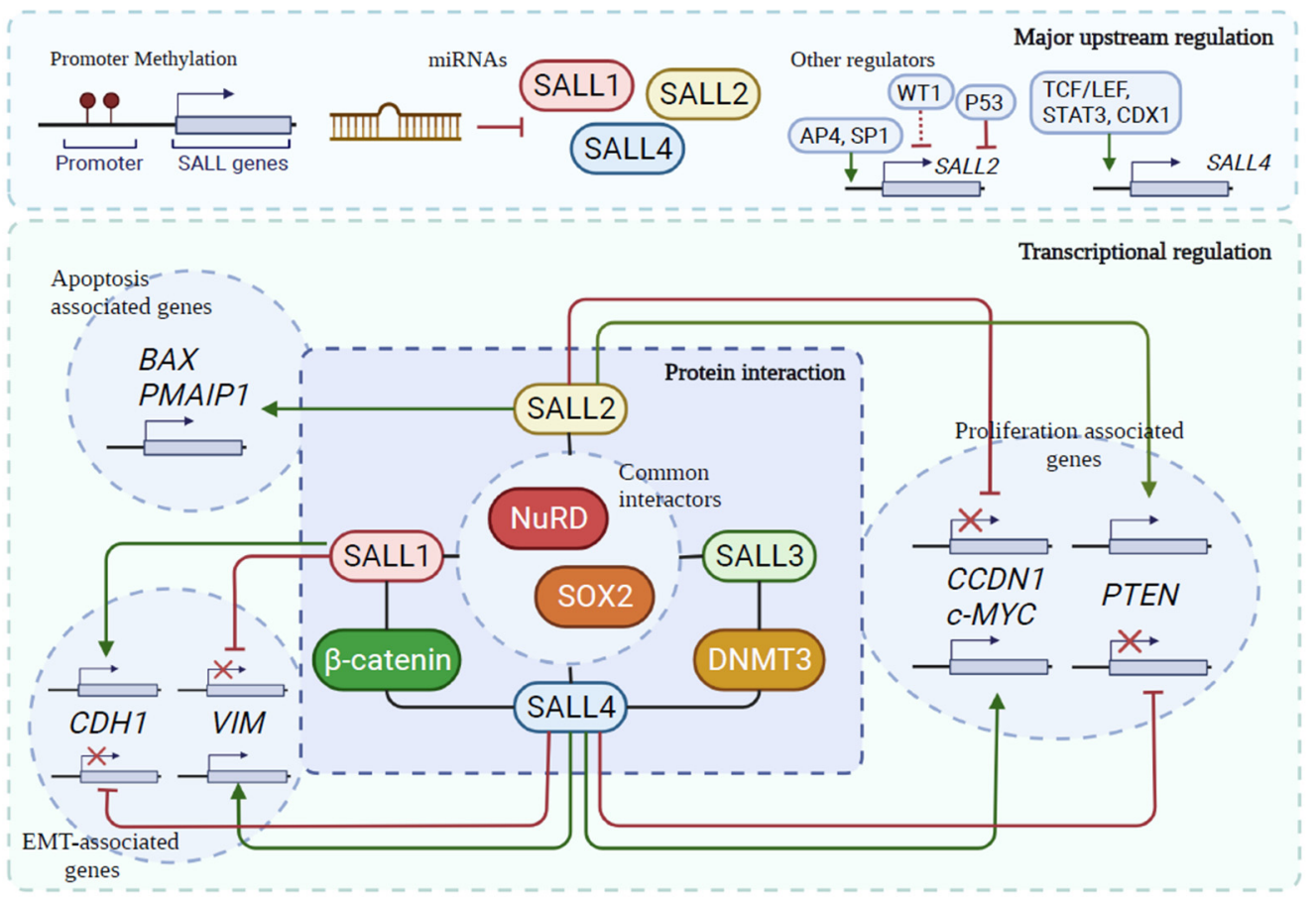

Figure 2. Common upstream regulation, partners, genes, and cellular functions of the SALL family. Epigenetic changes, including gene hypermethylation, hypomethylation, and miRs, are common mechanisms of SALL regulation. SALL1-3 promoters are hypermethylated in several cancers [54,55,92-97]. In contrast, the SALL4 promoter is hypomethylated in AML and MDS [98,99] and regulated by miRNAs in multiple cancer types [100]. Additionally, SALL1 and SALL2 are regulated by miRs (Table 1). Regulation by specific transcription factors depicted for SALL2 and SALL4. SALL proteins interact with specific partners to perform their functions; shared protein partners among the family include $\beta$-catenin and DNMT3. In addition, the four SALLs interact with the NuRD complex and with SOX2. Common transcriptional targets of SALLs are associated with cell proliferation and migration/invasion. SALL2 and SALL4 oppositely regulate CCDN1, c-MYC, and PTEN. Similarly, SALL1 and SALL4 oppositely regulate CDH1 (E-cadherin) and VIM (vimentin). However, SALL1 and SALL4 are both negative regulators of PTEN. Moreover, apoptosis-associated genes, such as BAX and PMAIP1 (NOXA), are regulated by SALL2. Green lines: positive regulation. Red lines: negative regulation. Dotted lines: proposed association. 
Table 1. Summary of all microRNAs known to regulate SALLs.

\begin{tabular}{|c|c|c|c|c|c|}
\hline $\begin{array}{c}\text { Cancer } \\
\text { Type/Cellular } \\
\text { Model }\end{array}$ & microRNA & Target & SALL Status/Key Findings & Experimental Approach & Ref. \\
\hline Glioma/Glioblastoma & miR-302/367 cluster & SALL2 & $\begin{array}{l}\text { miR-302/367 cluster can reprogram tumor } \\
\text { cells, generating more benign phenotypes } \\
\text { by suppressing OCT3/4, SOX2, KLF4, } \\
\text { c-MYC, POU3F2, OLIG2, and SALL2 }\end{array}$ & $\begin{array}{l}\text { qRT-PCR, cytokine array } \\
\text { analysis }\end{array}$ & [101] \\
\hline Glioma/Glioblastoma & miR-16 & SALL4 & $\begin{array}{c}\text { miR-16 inhibits proliferation, migration, } \\
\text { and invasion in glioma cells by directly } \\
\text { targeting SALL4 }\end{array}$ & $\begin{array}{l}\text { qRT-PCR and Luciferase } \\
\text { reporter assay }\end{array}$ & [102] \\
\hline Glioma/Glioblastoma & $\begin{array}{l}\mathrm{miR}-103 / \mathrm{miR}- \\
195 / \mathrm{miR}-15-\mathrm{B}\end{array}$ & SALL4 & $\begin{array}{c}\text { miR-103, miR-195, and miR-15-B inhibit } \\
\text { proliferation, migration, and invasion and } \\
\text { promote apoptosis in glioma by directly } \\
\text { targeting SALL4 }\end{array}$ & $\begin{array}{l}\text { qRT-PCR, Western blot, and } \\
\text { Luciferase reporter assay }\end{array}$ & [103] \\
\hline Glioma/Glioblastoma & miR-107 & SALL4 & $\begin{array}{l}\text { miR-107 inhibits proliferation and } \\
\text { promotes apoptosis in glioma cells by } \\
\text { directly targeting SALL4 }\end{array}$ & $\begin{array}{l}\text { qRT-PCR, Western blot, and } \\
\text { Luciferase reporter assay }\end{array}$ & [104] \\
\hline Glioma/Glioblastoma & miR-181b & SALL4 & $\begin{array}{l}\text { miR-181b inhibits proliferation, migration, } \\
\text { and invasion and promotes apoptosis in } \\
\text { glioma by directly targeting SALL4 }\end{array}$ & $\begin{array}{l}\text { qRT-PCR, Western blot, and } \\
\text { Luciferase reporter assay }\end{array}$ & [105] \\
\hline Gastric cancer & miR188-5p & SALL4 & $\begin{array}{c}\mathrm{miR}-188-5 \mathrm{p} \text { promotes proliferation and } \\
\text { migration by upregulating SALL4 } \\
\text { expression, nuclear translocation, and } \\
\text { transcription }\end{array}$ & $\begin{array}{l}\text { qRT-PCR, Western blot, and } \\
\text { Luciferase reporter assay }\end{array}$ & [106] \\
\hline Gastric cancer & miR-16 & SALL4 & $\begin{array}{c}\text { miR-16 inhibits proliferation and } \\
\text { migration in GC by directly targeting } \\
\text { SALL4 }\end{array}$ & $\begin{array}{l}\text { qRT-PCR and Luciferase } \\
\text { reporter assay }\end{array}$ & [107] \\
\hline Colorectal cancer & miR-181a-2* & SALL1 & $\begin{array}{l}\text { miR-181a- } 2 * \text { correlates with a trend of } \\
\text { repression of SALL1 and high methylation } \\
\text { status of the SALL1 promoter }\end{array}$ & $\begin{array}{l}\text { qRT-PCR and bisulfite } \\
\text { modification followed by } \\
\text { quantitative methylation- } \\
\text { specific PCR (qMSP) }\end{array}$ & [108] \\
\hline Colorectal cancer & miR-219-5p & SALL4 & $\begin{array}{l}\text { miR-219-5p inhibits proliferation, } \\
\text { migration, and invasion, reduces drug } \\
\text { resistance, and promotes apoptosis in } \\
\text { CRC by directly targeting SALL4 }\end{array}$ & $\begin{array}{l}\text { qRT-PCR, Western blot, and } \\
\text { Luciferase reporter assay }\end{array}$ & [109] \\
\hline Colorectal cancer & $\operatorname{miR}-3622 a-3 p$ & SALL4 & $\begin{array}{l}\text { miR-3622a-3p inhibits proliferation, cell } \\
\text { cycle, migration, invasion, and stemness } \\
\text { features and promotes apoptosis by } \\
\text { targeting SALL4 }\end{array}$ & $\begin{array}{l}\text { qRT-PCR, Luciferase assay, } \\
\text { RNA immunoprecipitation } \\
\text { (RIP) assay, and pull-down } \\
\text { assay }\end{array}$ & [110] \\
\hline Embryonic stem cell & miR15-B & SALL4 & $\begin{array}{l}\text { Anti-miR-15b enhances expansion of HSC } \\
\text { in vitro by targeting SALL4 }\end{array}$ & qRT-PCR & [111] \\
\hline Embryonic stem cell & $\begin{array}{l}\text { miR-294 and let-7 } \\
\text { miRNAs }\end{array}$ & SALL4 & $\begin{array}{l}\text { Let-7 miR family inhibits self-renewal } \\
\text { genes, and miR-294 indirectly induces } \\
\text { self-renewal genes, including SALL4 }\end{array}$ & $\begin{array}{l}\text { qRT-PCR, Western blot, and } \\
\text { Luciferase reporter assay }\end{array}$ & [112] \\
\hline $\begin{array}{l}\text { Oral squamous cell } \\
\text { carcinoma }\end{array}$ & miR-103 & SALL4 & $\begin{array}{c}\text { miR-103 inhibits cell proliferation and } \\
\text { invasion by downregulating SALL4 } \\
\text { mRNA in Tca } 8113 \text { cells }\end{array}$ & Luciferase reporter assay & [113] \\
\hline Breast cancer & $\begin{array}{l}\text { SNHG12 and } \\
\text { miR-15a-5p }\end{array}$ & SALL4 & $\begin{array}{l}\text { Long non-coding RNA (lncRNA) small } \\
\text { nucleolar RNA host gene } 12 \text { (SNHG12) } \\
\text { promotes proliferation, migration, and } \\
\text { invasion and inhibits apoptosis in breast } \\
\text { cancer by upregulating SALL4 expression } \\
\text { via sponging miR-15a-5p; SALL4 is a } \\
\text { direct target of miR-15a-5p }\end{array}$ & $\begin{array}{l}\text { qRT-PCR, Western blot, and } \\
\text { Luciferase reporter assay }\end{array}$ & [114] \\
\hline Renal cell carcinoma & miR-942 & SALL1 & $\begin{array}{l}\text { miR- } 942 \text { affects survival of patients with } \\
\text { renal cell carcinoma by negatively } \\
\text { regulating the expression of SALL1 }\end{array}$ & RNA-seq and qRT-PCR & [115] \\
\hline Prostate cancer & $\operatorname{miR}-4286$ & SALL1 & $\begin{array}{l}\text { miR- } 4286 \text { regulates proliferation and } \\
\text { apoptosis in PCa cells by directly targeting } \\
\text { the } 3^{\prime} \text { UTR of SALL1 mRNA }\end{array}$ & $\begin{array}{l}\text { qRT-PCR and Luciferase } \\
\text { reporter assay }\end{array}$ & [116] \\
\hline Lung cancer & $\begin{array}{l}\text { HOXA11-AS and } \\
\text { miR-3619-5p }\end{array}$ & SALL4 & $\begin{array}{c}\text { lncRNA homeobox A11 antisense } \\
\text { (HOXA11-AS) promotes proliferation, } \\
\text { migration, invasion, and glycolysis in } \\
\text { non-small cell lung cancer (NSCLC) cells } \\
\text { by upregulating SALL4 expression via } \\
\text { sponging miR-3619-5p; SALL4 is a direct } \\
\text { target of miR-3619-5p }\end{array}$ & $\begin{array}{l}\text { qRT-PCR, Western blot, and } \\
\text { Luciferase reporter assay }\end{array}$ & [117] \\
\hline
\end{tabular}


Table 1. Cont.

\begin{tabular}{|c|c|c|c|c|c|}
\hline $\begin{array}{l}\text { Cancer } \\
\text { Type/Cellular } \\
\text { Model }\end{array}$ & microRNA & Target & SALL Status/Key Findings & Experimental Approach & Ref. \\
\hline Osteosarcoma & $\begin{array}{l}\text { ZEB2-AS1 and } \\
\text { miR-107 }\end{array}$ & SALL4 & $\begin{array}{l}\text { IncRNA ZEB2-AS1 (ZEB2-AS1) promotes } \\
\text { proliferation, invasion, and metastasis and } \\
\text { inhibits apoptosis in osteosarcoma cells by } \\
\text { upregulating SALL4 expression via } \\
\text { sponging miR-107; SALL4 is a direct } \\
\text { target of miR-107 }\end{array}$ & $\begin{array}{l}\text { qRT-PCR, Luciferase assay, } \\
\text { and RNA pull-down assay }\end{array}$ & [118] \\
\hline $\begin{array}{l}\text { Hepatocellular } \\
\text { carcinoma }\end{array}$ & miR-296-5p & SALL4 & $\begin{array}{l}\text { miR-296-5p inhibits stemness potency of } \\
\text { hepatocellular carcinoma (HCC) cells via } \\
\text { the Brg1/Sall4 axis; Brg1 binds to the } \\
\text { SALL4 promoter }\end{array}$ & $\begin{array}{l}\text { qRT-PCR, Western blot, } \\
\text { Luciferase reporter assay, } \\
\text { and Chromatin } \\
\text { immunoprecipitation } \\
\text { (ChIP) assay }\end{array}$ & [119] \\
\hline $\begin{array}{l}\text { Hepatocellular } \\
\text { carcinoma }\end{array}$ & miR-15a & SALL4 & $\begin{array}{l}\text { Exosomal miR-15a reduces proliferation, } \\
\text { migration, invasion, and survival by } \\
\text { directly targeting SALL4 }\end{array}$ & $\begin{array}{l}\text { qRT-PCR, Western blot, and } \\
\text { Luciferase reporter assay }\end{array}$ & [120] \\
\hline
\end{tabular}

Promoter hypermethylation is frequent for SALL1, SALL2, and SALL3, and the regulation of $3^{\prime}$ UTR by miRNAs appears as a typical regulatory mechanism for SALL4. Epigenetic modifications on $S A L L$ genes are consistent with their prominent roles as tumor suppressors or oncogenes. For instance, associated with their tumor suppressor role, the hypermethylation of the SALL1 and SALL2 promoters were described in breast cancer and esophageal squamous cell carcinoma (ESCC) $[54,55,92,93]$. The hypermethylation of the $S A L L 2$ promoter was associated with aggressive and tamoxifen-resistant breast cancer phenotypes [54]. In oral squamous cell carcinoma (OSCC), SALL2 promoter hypermethylation positively correlates with SALL1 and SALL3 promoter methylation status and aggressive tumor behavior [94].

The SALL promoters are also aberrantly methylated in HPV-related cancers. Several studies indicate that the hypermethylation of SALL1 and SALL3 promoters correlates with poor outcomes and recurrence in head and neck squamous cell carcinoma (HNSCC) [95-97]. However, SALL4 is upregulated in this type of cancer, and its expression correlates with disease recurrence and decreased disease-free survival. High SALL4 expression positively correlated with DNA methyltransferase 3 alpha (DNMT3A) expression and the increased methylation rate of 11 tumor suppressor genes. Still, there was no significant correlation between SALL4 expression and SALL1, SALL2, and SALL3 methylation status [121]. Aberrant hypomethylation of the SALL4 promoter is described as a common event in AML and myelodysplastic syndrome (MDS) [98,99].

Table 1 shows the repertory of miRNAs regulating SALL1, SALL2, and SALL4 in different cancer types. Most of them target SALL4, and some miRNAs are common among cancers. More specifically for SALL4, miR-16 is common in glioma and gastric cancer, miR103 in glioma and oral squamous cell carcinoma, and miR-107 in glioma and osteosarcoma. For more comprehensive information on SALL4 and miRNAs and the strategies targeting the miR/SALL4 axis in cancer, see a recent review by Liu J and collaborators [100].

These studies identified common upstream regulation, targets, and cellular functions. However, their effects seem to be opposite or synergic, depending on the tumor context and the implicated SALL protein. Concerning the role of SALL3 in cancer development and progression, the available information is still scarce, but we will discuss recent studies on SALL3 by cancer subtype in the next section. In Figure 2, we illustrate SALL proteins' shared targets, partners, cellular functions, and regulatory mechanisms. 


\section{SALL Proteins in Cancer}

SALL proteins are altered in various cancer types (Table 2 and Figure 3). Alterations include deregulation in gene expression, isoform expression, and genetic aberrations. We focused our analysis on those cancer types with the most considerable data on SALL family members.

Table 2. Deregulation of SALLs in other cancers.

\begin{tabular}{|c|c|c|c|c|c|c|}
\hline Cancer Type & $\begin{array}{l}\text { SALL } \\
\text { Member }\end{array}$ & $\begin{array}{l}\text { Expression } \\
\text { Levels }\end{array}$ & $\begin{array}{l}\text { Genetic Alter- } \\
\text { ation/Regulation }\end{array}$ & $\begin{array}{l}\text { Association With } \\
\text { Cancer/Biological Process }\end{array}$ & $\begin{array}{l}\text { Proposed } \\
\text { Cancer Role }\end{array}$ & Ref. \\
\hline Lung & SALL1 & High & Undescribed & $\begin{array}{l}\text { Expression correlated with lower overall } \\
\text { survival of NSCLC patients }\end{array}$ & Oncogene & [122] \\
\hline Lung & SALL2 & Low & $\mathrm{LOH}$ & $\begin{array}{c}\text { Undescribed } \\
\text { Expressed in } 88 \% \text { f }\end{array}$ & Undescribed & [71] \\
\hline Lung & SALL4 & High & Undescribed & $\begin{array}{l}\text { samples } \\
\text { May be used as a diagnostic marker }\end{array}$ & Oncogene & [123] \\
\hline Lung & SALL4 & High & Undescribed & $\begin{array}{l}\text { SALL4 knockdown inhibits cell } \\
\text { proliferation by cell cycle arrest at the } \\
\text { GO/G1 phase } \\
\text { Loss of SALL4 function inhibits migration, } \\
\text { invasion and reduces the transplanted } \\
\text { tumors size in an in vivo model }\end{array}$ & Oncogene & [43] \\
\hline Lung & SALL4 & High & Undescribed & $\begin{array}{l}\text { SALL4 silencing sensitizes cells to cisplatin, } \\
\text { carboplatin, and paclitaxel treatment }\end{array}$ & Oncogene & [124] \\
\hline Esophageal & SALL1 & Low & Hypermethylation & $\begin{array}{l}\text { SALL1, ADHFE1, EOMES, and TFPI2 are } \\
\text { proposed as part of a tumor suppressors } \\
\text { panel with diagnostic relevance }\end{array}$ & $\begin{array}{l}\text { Tumor } \\
\text { suppressor }\end{array}$ & $\begin{array}{l}{[93} \\
125]\end{array}$ \\
\hline Esophageal & SALL2 & $\begin{array}{l}\text { Low in } \\
\text { radioresistant } \\
\text { ESCC cell lines }\end{array}$ & Hypermethylation & $\begin{array}{l}\text { SALL2 overexpression enhances apoptosis } \\
\text { after radiation and decreases migration, } \\
\text { viability, and cisplatin resistance in TE- } 1 / \mathrm{R} \\
\text { and Eca-109/R cell lines }\end{array}$ & $\begin{array}{l}\text { Tumor } \\
\text { suppressor }\end{array}$ & [55] \\
\hline Esophageal & SALL4 & High & Undescribed & $\begin{array}{c}\text { SALL4 silencing in ESCC cells is associated } \\
\text { with suppressing cell migration, invasion, } \\
\text { viability, and drug resistance in vivo } \\
\text { SALL4 knockdown reduces } \\
\text { epithelial-mesenchymal transition by } \\
\text { targeting the Wnt/ } \beta \text {-catenin signaling } \\
\text { pathway }\end{array}$ & Oncogene & $\begin{array}{l}{[42,} \\
126]\end{array}$ \\
\hline Bladder & SALL2 & Low & $\mathrm{LOH}$ & Undescribed & $\begin{array}{l}\text { Tumor } \\
\text { suppressor }\end{array}$ & [70] \\
\hline Bladder & SALL3 & Low & Hypermethylation & $\begin{array}{c}\text { SALL3, CFTR, and TWIST1 are proposed as } \\
\text { disease recurrence predictors }\end{array}$ & $\begin{array}{l}\text { Tumor } \\
\text { suppressor }\end{array}$ & $\begin{array}{l}{[127,} \\
128]\end{array}$ \\
\hline $\begin{array}{l}\text { Testicular } \\
\text { tumors }\end{array}$ & SALL4 & High & Undescribed & $\begin{array}{l}\text { SALL4 is a novel sensitive and specific } \\
\text { marker for testicular germ cell tumors }\end{array}$ & Oncogene & [129] \\
\hline Kidney & SALL1 & Low & miR-942 & $\begin{array}{l}\text { SALL1 inhibition plays a potential role in } \\
\text { sunitinib resistance in RCC patients }\end{array}$ & $\begin{array}{l}\text { Tumor } \\
\text { suppressor }\end{array}$ & [115] \\
\hline Wilms' tumor & SALL1 & High & Undescribed & Undescribed & Oncogene & $\begin{array}{l}{[130} \\
131]\end{array}$ \\
\hline Wilms' tumor & SALL2 & High & Undescribed & $\begin{array}{l}\text { SALL2 was identified as one of the } 27 \\
\text { signature genes highly expressed by } \\
\text { comparing tumor samples with normal } \\
\text { fetal kidneys }\end{array}$ & Oncogene & [132] \\
\hline Kidney & SALL3 & Low & Methylation & $\begin{array}{l}\text { SALL3 downregulation may contribute to } \\
\text { genome hypermethylation similar to VHL }\end{array}$ & $\begin{array}{l}\text { Tumor } \\
\text { suppressor }\end{array}$ & [133] \\
\hline Wilms' tumor & SALL4 & High & Undescribed & Undescribed & Oncogene & [134] \\
\hline
\end{tabular}




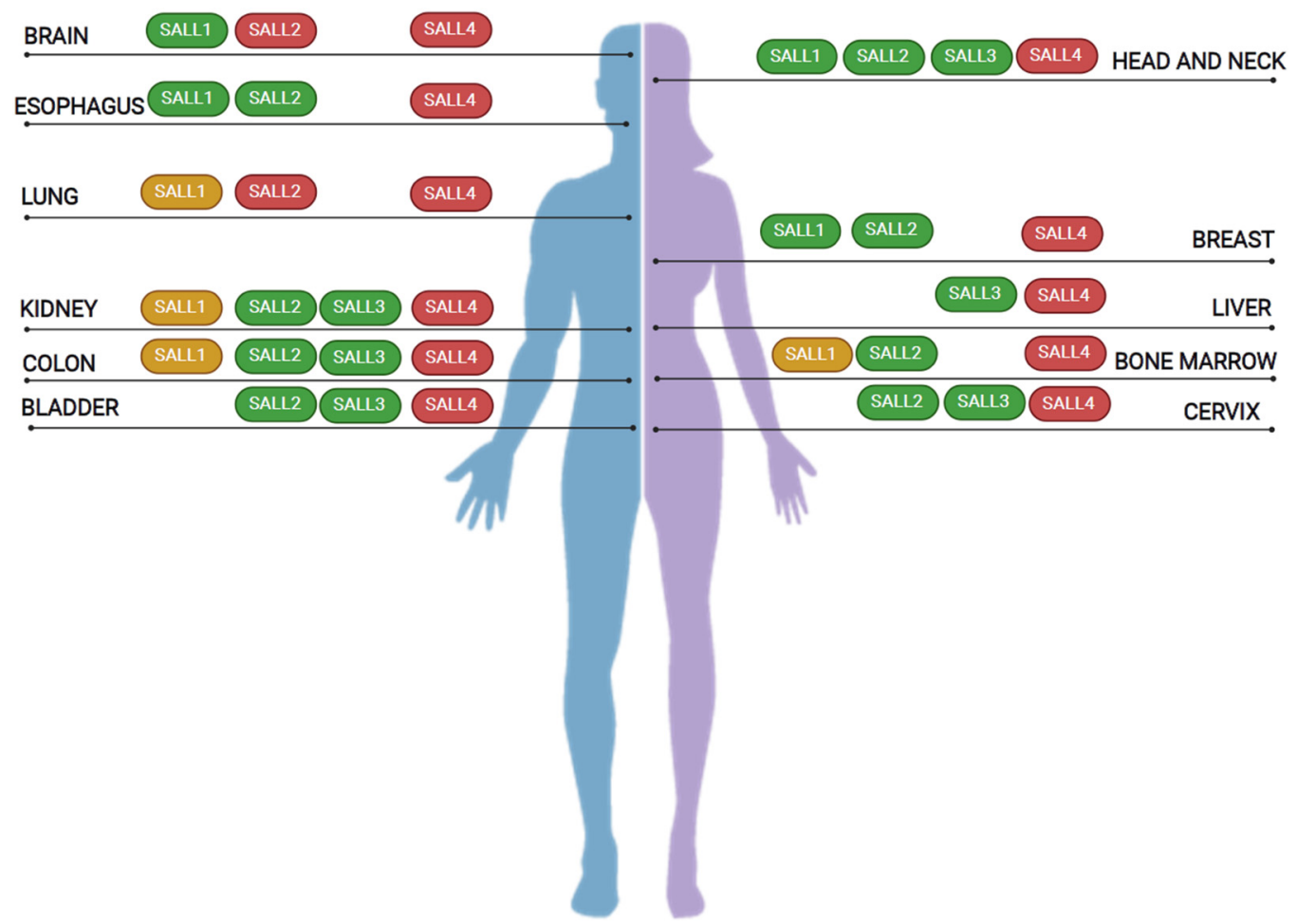

Figure 3. SALL proteins in cancer. SALL proteins are deregulated in major cancer types, including lung, colon, and breast cancers. As shown above, independent studies identified alterations in more than one family member in specific cancer types. According to genetic alterations, isoform expression, and changes in their expression, they are classified as oncogenes (red), tumor suppressors (green), or genes with a dual role in cancer (yellow).

\subsection{Breast Cancer}

Breast cancer is the most diagnosed tumor and the leading cause of cancer death among women worldwide. Thus, understanding its molecular mechanisms has become necessary for early diagnosis and successful treatment. The intrinsic classification of breast cancer distinguishes four subtypes: luminal A, luminal B, basal-like, and HER2-positive. This classification allows for the development of specific types of clinical management for breast cancer patients. In this line, the expression of the estrogen receptor (ER), progesterone receptor (PR), and HER2 biomarkers are related to a better prognosis and response to therapy in breast cancer patients than those with the absence of these biomarkers [135]. Several independent studies suggest that SALL1, SALL2, and SALL4 play a role in the origin, progression, and response to breast cancer therapy.

SALL2 is a putative target gene of MYB, a transcription factor predicted as a prognostic gene signature across molecular breast cancer subtypes. More importantly, MYB and SALL2 were suggested to attenuate histological grade promotion and prevent breast cancer progression [136]. In addition, a differentially weighted graphical LASSO analysis showed SALL2 to be among the top 10 genes that are highly relevant in studies on the discovery of breast cancer biomarkers [137]. In addition, a transcription profiling analysis identified SALL2 to have been significantly reduced during tamoxifen therapy by a mechanism that involves the hypermethylation of the SALL2 promoter. SALL2 transcriptionally upregulates estrogen receptor-alfa (ESR1) and PTEN, and directly binds to their promoters. Accordingly, the depletion of SALL2 decreased ESR1 and PTEN expression, activated the Akt/mTOR signaling, and resulted in estrogen-independent growth and tamoxifen resistance in ER $\alpha$ positive breast cancer. Of relevance here is 5-azacitidine, a DNMTi (DNA methyltransferase inhibitor), which triggered SALL2 restoration and sensitized tamoxifen-resistant breast cancer to tamoxifen therapy in vivo [54]. Consistent with the negative regulation of cell proliferation by SALL2 [26,38], bioinformatic studies using public data and R2 software 
showed a negative correlation between SALL2 and CCNE1 in breast cancer samples [26]. The studies above suggest that SALL2 behaves as a tumor suppressor in breast cancer.

Similar to SALL2, SALL1 is downregulated in human breast cancer cells and tissues and correlates with ESR1 expression. An immunohistochemistry analysis of 17 tissues indicated that the number of SALL1 positive cells is significantly higher in estrogen receptorpositive (ER+) than in estrogen receptor-negative (ER-) patients [36]. Five-azacitidine also restored SALL1 expression on methylated breast cancer cell lines [92]. Consistent with its tumor suppressor role in breast cancer, SALL1 inhibited tumor growth, metastasis in the lung and liver, and promoted cell cycle arrest and senescence. Mechanistically, SALL1-dependent growth inhibition and senescence involved the recruitment of the NuRD complex and the activation of the p38 MAPK, ERK1/2, and mTOR signaling pathways [36]. Similarly, SALL1 knockdown led to the differential expression of EMT markers, such as E-cadherin and vimentin in SUM149 breast cancer cells, leading to increased cell migration in vitro. Moreover, SALL1-knockdown SUM149 cells xenografted into immunodeficient NSG mice resulted in a significantly decreased tumor-free survival [138].

Unlike SALL1 and SALL2, studies showed higher SALL4 expression in breast cancer cell lines and primary tissues than their non-tumoral counterparts $[45,90,139]$. This high expression of SALL4 positively correlated with tumor size and lymphatic metastasis [45]. Functionally, SALL4 knockdown inhibited cell proliferation and induced the G0/G1 cell cycle arrest of MDA breast cancer cells, an effect explained by the SALL4 positive regulation of the $\mathrm{Wnt} / \beta$-catenin pathway in breast tumors [45]. In addition, in vitro SALL4 knockdown decreased migratory cell ability and promoted focal adhesion dynamics by the negative regulation of EMT-related markers (ZEB1, vimentin, and integrin $\alpha 6 \beta 1$ ), which was directly associated with E-cadherin recovery $[140,141]$. Consistent with the previous results, in vivo studies indicated that vimentin regulation by SALL4 enhances EMT, mammosphere formation, and tumorigenicity. SALL4 deficiency reduced lung colonization in MDA-MB-231 cells [142] and was associated with triple-negative (ER-, PR-, and HER2-) phenotypes [143]. Nevertheless, a recent study from 371 breast cancer patients showed that SALL4 expression positively correlates with PR protein level. PR was related to breast cancer stemness in vitro, similar to SALL4 [142]. For an extensive review on SALL4 and breast cancer, refer to [143].

Altogether, studies suggest that in breast cancer, SALL1 and SALL4 are involved in migration, invasion, and EMT by regulating common targets such as E-cadherin and vimentin, but in an opposite manner. Moreover, SALL1 and SALL2 act as tumor suppressors and are associated with proliferation arrest, ESR1 expression, and good prognosis. SALL1, SALL2, and ESR1 expression analyses could help to categorize breast cancer patients who may benefit from combined therapies: tamoxifen and DNMTi. The restoration of SALL2 and SALL1 expression with DNMTi may directly impact breast cancer treatment, increasing tamoxifen sensitivity in tamoxifen-resistant breast cancers.

\subsection{Brain Tumors}

Glioma refers to a primary brain or spinal tumor that derives from the neuroglial stem or progenitor cells. Glioblastoma multiforme (GBM) is the most malignant and frequently occurring type of brain cancer. Despite advances in treatment approaches, it remains incurable [144]. To date, all studies regarding the role of SALL proteins in brain tumors are focused on GBM.

Unlike its tumor suppressor role in breast and ovarian cancer $[4,38,145,146]$, SALL2 is part of the four-core neurodevelopmental transcription factors (including POU3F2, SOX2, and OLIG2) in GBM, which are sufficient to fully reprogram differentiated glioblastoma cells (DGCs) into stem-like tumor propagating cells (TPCs). In this context, SALL2 binds and activates TPC-specific regulatory elements. However, its interaction with the DNA is not associated with the previously CG-rich consensus motif identified by $\mathrm{Gu}$ and collaborators, found in cell cycle and pro-apoptotic gene promoters [49,65]. Instead, in the GBM context, SALL2 interacts with SOX2, which could explain the binding of SALL2 to 
SOX-like AT-rich elements [6]. Loss of function experiments through the induction of the miR-302/367 cluster in U87 cells revealed the importance of SALL2 and the other three transcription factors in brain tumor malignancy [101]. It was further supported by using lipopolymeric nanoparticle-containing combo siRNA (OLIG2, POU3F2, SALL2, and SOX2) targeting brain tumor-initiating cells (BTICs) in a mouse brain tumor model. The combo siRNA downregulated the PI3K/AKT and the STAT3 signaling, decreasing tumorigenicity and providing survival benefits [147]. These results opened possible avenues for future therapies that target brain tumor-initiating cells.

SALL4 has also been associated with increased tumorigenicity due to higher expression levels in GBM human samples as compared with normal brain tissue. The analysis of 524 GBM patients from the TCGA database showed a robust negative correlation between SALL4 expression and overall survival [148]. Furthermore, SALL4 silencing in the U87 and U251 GBM cell lines reduced cell proliferation by increasing PTEN expression and decreasing the PI3K/AKT pathway activity, triggering G1 cell cycle arrest [44].

On the other hand, SALL1 downregulation has been described in cerebral glioma tissues, correlating with higher tumor grade and lower survival. The overexpression of SALL1 in the U87 and U251 GBM cell lines induced a decrease in the expression of $\beta$-catenin, c-MYC, cyclin D1, and EMT markers, impairing migratory and invasive cell capacity. It also increased p21 and p27 expression, leading to G0/G1 cell cycle arrest [149].

In summary, SALL1 functions as a putative tumor suppressor in GBM, but SALL2 and SALL4 are crucial for tumor development and progression, which is associated with PI3K/AKT pathway activation and the maintenance of an undifferentiated aggressive phenotype.

\subsection{Blood Cancers}

Hematological malignancies correspond to a heterogeneous group of lymphoid and myeloid neoplasms caused by the deregulation of normal hematopoietic processes. They include leukemias, lymphoma, and multiple myelomas and are classified based on genetics, immunophenotype, morphology, and molecular and clinical characteristics [150]. SALL1, SALL2, and SALL4 were associated with hematological malignancies.

Two independent genome-wide analyses confirmed the hypermethylation of the aberrant SALL1 promoter in human samples of acute lymphocytic leukemia (ALL) and chronic lymphocytic leukemia (CLL). SALL1 hypermethylation correlated with worse overall survival in patients $[151,152]$. Furthermore, SALL1 seems to have an oncogenic role in acute myeloid leukemia (AML). SALL1 silencing decreased human primary AML cell proliferation, resulted in low AML engraftment into NSG mice, and correlated with the upregulation of PTEN and the downregulation of mTOR, $\beta$-catenin, and NF-қB expression. This oncogenic role of SALL1 in AML may be associated with the expression of SALL1 isoform 2, characterized by the loss of exon 1 (Figure 1). SALL1 isoform 2 is expressed in AML but not in normal bone marrow, suggesting that this isoform has a different behavior than other SALL1 isoforms [9]. Thus, depending on the hematological malignancy, SALL1 could play different roles, as a tumor suppressor in lymphoid progenitor-derived leukemia (ALL-CLL) and as an oncogene in myeloid progenitor-derived leukemia (AML). Identifying the SALL1 isoform deregulated in ALL and CLL could help define the role and mechanisms of SALL1 in leukemia.

SALL2 is expressed in normal bone marrow but absent or weak in AML samples, suggesting that lost or reduced SALL2 expression is related to myeloid leukemogenesis. Moreover, Sall2 ${ }^{-/-}$or Sall2 ${ }^{-/+} / p 53^{-/-}$mice showed enhanced tumorigenesis, lymphoma progression, metastasis, and mortality rate compared with the Sall $2^{+++} / p 53^{-/-}$mice [25]. Interestingly, Histone Deacetylase Inhibitor (HDACi) TSA treatment induced SALL2dependent apoptosis in Jurkat T cells. The genomic deletion of SALL2 suppressed PARP cleavage, decreased apoptotic cell population, and increased cell viability under TSA treatment. In contrast, the overexpression of SALL2 decreased cell viability. These data 
indicate that SALL2 is required for the apoptotic response in Jurkat T cells, an acute $\mathrm{T}$ cell leukemia model, thus supporting its role as a tumor suppressor [51].

SALL4 is highly expressed in hematopoietic malignancies and is associated with deteriorated disease status in patients [153]. Three SALL4 functional isoforms were identified in blood cancers in humans and mice (A, B, and C). Most studies are on the A and $B$ variants (Figure 1). SALL4A is the full-length isoform, and SALL4B lacks exon 2 [12]. In transgenic mouse model studies, the SALL4A and SALL4B isoforms bound $\beta$-catenin, synergistically activating the WNT/ $\beta$-catenin pathway, which plays a critical role in controlling leukemia stem cell self-renewal [154]. SALL4 also promoted leukemogenesis by repressing the tumor suppressor PTEN, similar to its breast cancer function. The mechanism involves the interaction of SALL4 with the histone deacetylase (HDAC) NuRD complex. Blocking SALL4/HDAC interaction with a peptide derived from the amino-terminal 12-amino-acid sequence of SALL4 led to higher PTEN expression and an antiproliferative effect on SALL4-expressing cancer cells. Of relevance here is that similar to SALL4 down-regulation, the SALL4 peptide treatment of primary AML cells impaired leukemic engraftment in vivo [155].

Together, these studies suggest that SALL1 and SALL2 play opposite roles in myeloid progenitor-derived leukemia, as oncogene and tumor suppressor, respectively. However, in lymphoid progenitor-derived leukemia (ALL-CLL), SALL1 could act as a tumor suppressor. SALL4 is oncogenic, required for leukemia stem cell self-renewal. Remarkably, both SALL1 and SALL4 positively regulate the WNT/ $\beta$-catenin pathway. For a more comprehensive overview of SALL4 research on blood cancers, refer to [153].

\subsection{Colorectal Cancer}

Colorectal cancer (CRC) is the second most diagnosed malignancy worldwide in women and the third in men [156]. Advances in CRC research have increased the disease treatment options. Despite new approaches in the treatment of CRC patients, none is entirely effective, resulting in high recurrence even after tumor resection. Thus, it is necessary to search for new targets to facilitate the diagnosis and treatment [156]. In this context, SALL proteins could have a promising role.

The epigenetic inactivation of SALL1 in epithelial cancers, including CRC, was identified using the MIRA (methylated-CpG island recovery assay) and $\mathrm{CpG}$ island arrays. SALL1 promoter methylation was present in $83 \%$ of CRC and $89 \%$ of adenomas, while methylation frequency in normal tissues was 38\% [92]. Additionally, Zhang and collaborators identified SALL1 and SALL3 as part of a high-risk group of genes differentially expressed within a vast number of genes whose methylation status also differed when comparing tumor and adjacent normal tissue. The study suggested SALL1 and SALL3 as being the new candidate biomarkers of poor prognosis in CRC. Epigenetic mechanisms partly mediate the loss of SALL1 and SALL3 in CRC [157]. Recently, SALL1 was identified as one of nine prognostic gene signatures predicting survival in CRC patients [158].

There are some conflicting studies on the expression of SALL4 in CRC. SALL4 is upregulated, and its expression positively correlates with tumor stage, metastasis to lymph nodes, and poor differentiation in CRC samples [159,160]. Accordingly, a Kaplan-Meier analysis conducted after five years of follow-up on 135 CRC patients associated SALL4 expression with a lower survival rate as compared to the SALL4 negative group [161]. However, an immunohistochemical analysis of 149 patients revealed the significantly lower expression of SALL4 in CRC (46.3\%) than in atypical hyperplasia (68.0\%) and normal tissue (78.9\%) [162]. However, as in previous studies, SALL4 expression positively correlated with lymph node metastasis, tumor node metastasis, and Dukes' stages. SALL4 and $\beta$-catenin positively correlated in CRC tissues and cells, showing co-localization and interaction [162]. This study suggested that the function of SALL4 in promoting lymph node metastasis and the advanced clinical stage is partly due to its interaction with $\beta$-catenin. In addition, the flavonoid chrysin treatment of CT29 murine CRC cells decreased SALL4 expression, resulting in apoptosis induction associated with increased BAX levels and caspase 3/9 
activity and with a decrease in tumor size in allograft assays [163]. The upregulation of SALL4 in CRC is partly due to the low aberrant expression of miR-3622a-3p, one of the SALL4 upstream negative regulators (Table 2). The overexpression of miR-3622a$3 p$ in CRC cells decreased stemness features and EMT-related markers via the targeting of SALL4 [110]. In addition, miR-219-5p also inhibited colon cancer carcinogenesis by targeting SALL4 [109].

There are no functional studies of SALL2 or SALL3 in CRC; however, loss of heterozygosity $(\mathrm{LOH})$ has been reported in the 14q12-13 region, a chromosomal region where the SALL2 gene is located [72]. Bioinformatic analysis of massive CRC public data indicates that SALL2 is significantly downregulated in CRC [6]. However, another recent bioinformatic study identified a positive correlation between SALL2 and the degree of tumor-stromal cell infiltrates in colon and rectum adenocarcinomas [164].

Interestingly, in a small-sample-size study of primary and metastatic tumors from four patients with CRC, SALL3 was identified as one of seventeen genes significantly upregulated in CD133+ cells as compared to CD133-CRC cells, suggesting its potential as a biomarker of CRC stemness [165]. Thus, SALL proteins can positively or negatively affect CRC progression by different pathways and mechanisms. However, additional studies are required to elucidate the role of the SALL proteins in CRC.

\subsection{Hepatocellular Carcinoma}

Hepatocellular carcinoma (HCC) is the most common primary liver cancer worldwide. Carcinogenesis is associated with alcohol consumption, smoking, and genetic background, but the primary cause is the hepatitis B virus (HBV) infection. A recent meta-analysis proposed an association between HBV infection and gene methylation in HCC development [166]. SALL3 tumor suppressor function was associated with CpG island methylation in HCC. SALL3 directly interacts with DNMT3A, decreasing CpG methylation status [167]. Thus, the epigenetic silencing of SALL3 increases DNMT3A binding to chromatin, resulting in aberrant CpG island methylation that should contribute to HCC development $[168,169]$.

Contrary to SALL3 hypermethylation, the SALL4 promoter is hypomethylated in HCC tissues and cell lines infected with HBV and the hepatitis C virus (HCV), which leads to the aberrant overexpression of the SALL4A and SALL4B isoforms [170]. Several studies demonstrated that the high expression of SALL4 in HCC is related to stem cell characteristics and poor prognosis [171-175]. SALL4 was detected in HCC, but its expression was weak in benign lesions and undetected in adjacent noncancerous hepatic tissues. Moreover, SALL4 was associated with $\alpha$-fetoprotein (AFP), a well-known diagnostic marker in HCC. The detection of SALL4 combined with AFP may be helpful for prognostic stratification. Patients with higher levels of SALL4 and AFP were associated with a worse prognosis [172]. Additionally, a recent investigation suggests that a quantitative analysis of the liver function by contrast-enhanced ultrasonography (CEUS) in conjunction with a quantitative analysis of the SALL4/Wnt/ $\beta$-catenin axis expression may serve as an early diagnosis method for HCC patients [176].

A recent study proposed that the inflammatory microenvironment promotes stemness and the metastatic phenotype in HCC via the NF- $\mathrm{KB} /$ miR-497/SALL4 axis. TNF- $\alpha$ activated NF- $\mathrm{KB}$ and repressed the miR-497 promoter. Consequently, the upregulation of SALL4 promoted stem cell self-renewal and metastasis [177]. On the other hand, SALL4 could impact the tumor microenvironment and support tumor progression by affecting the HCC exosome content. SALL4 bound to the miR-146a-5p promoter and positively regulated its expression in HCC exosomes. The miR-146a-5p from exosomes increased the number of M2-polarized tumor-associated macrophages that support tumor progression [178].

Altogether, the evidence points to SALL4 as a potential candidate for HCC therapy. Additionally, SALL3's relationship with global methylation appears to be an attractive field of study. Demethylating agents are increasingly being used and proposed for clinical trials in different tumors, including HCC [179]. 


\subsection{HNSCC and Cervical Cancer}

Strong evidence associates the human papillomavirus (HPV) with several human diseases, including cancer. To date, more than $170 \mathrm{HPV}$ genotypes have been described, of which the high-risk HPV (HR-HPV) types 16, 18, 31, 33, and 35 are related to malignancies such as cervical carcinoma and head and neck squamous cell carcinoma (HNSCC). HNSCC includes a heterogeneous group of malignancies that arise in the oral cavity, pharynx, or larynx [180].

The first study that associated SALL proteins with HPV-related cancer showed that oncoprotein E6 from HR-HPV infection binds SALL2 and induces its stabilization in cervical cancer cells. This interaction prevented the binding of SALL2 to the p21 promoter, leading to the accumulation of inactive SALL2 in SiHa, Caski, and HeLa HR-HPV positive cervical cancer cell lines [146]. However, the cellular location and significance of the inactive SALL2 protein in cervical and other HPV-related cancers require further investigation.

Subsequent evidence of a relation between SALLs and HPV-related cancers conveys their epigenetic regulation. The hypermethylation of the $S A L L 3$ promoter was described in different HPV-related cancer cell lines and tissues such as cervical cancer and HNSCC $[95,96,181]$. SALL3 hypermethylation correlates with reduced disease-free survival (DFS) in stage III and IV HNSCC patients [96]. Moreover, the SALL3 chromosomal locus is part of a region with genes identified as significant prognostic biomarkers in HNSCC patients. Here, $\mathrm{LOH}$ on chromosome $18 \mathrm{q} 23$ is associated with significantly decreased survival in HNSCC patients [95]. Similar to SALL3, SALL1 is aberrantly hypermethylated in HNSCC. It correlates with reduced DFS in early-stage T1 and T2 patients and with the methylation status of the SALL3 promoter [97]. In the same context, SALL2 hypermethylation correlated with the methylation status of SALL1 and SALL3. Thus, more than one SALL (SALL1-3) hypermethylation positively correlates with a worse prognosis and lower DFS in HNSCC [94]. In contrast to SALL1 and SALL3, high SALL4 expression is correlated with disease recurrence and decreased DFS rates in HNSCC [121]. SALL4 expression increased G1 to the S-phase cell cycle progression in cervical cancer cell lines by a mechanism that involves the increment of $\beta$-catenin expression, a necessary cofactor for activating the Wnt/ $\beta$-catenin signaling pathway involved in cell proliferation [41].

In summary, members of the SALL family are related to HNSCC and cervical carcinoma, with a loss of function of SALL1-3 by epigenetic silencing. Furthermore, SALL4 upregulation is associated with a poor prognosis. The involvement of SALL proteins in other HPV-related cancers such as penile, vulvar, vaginal, or anal cancer awaits investigation.

\section{Targeting SALLs for Cancer Therapy}

Considering the evidence on the role of the SALL family members in cancer initiation and progression, targeting SALLs provides a unique therapeutic opportunity for cancer treatments.

Even though transcription factors have remained challenging drug targets, several in vitro and in vivo approaches targeting SALL4 protein activity have already been investigated.

The HDAC-1 and -3 inhibitor Entinostat was identified as a potential treatment for SALL4-expressing cancers. The study used a panel of 17 lung cancer cell lines with varied SALL4 expression levels, showing that cells expressing high levels of SALL4 were more sensitive to Entinostat treatment [182]. However, HDAC inhibitors are not selectively targeting SALL4 expressing cells. Pharmacological peptides that exclusively target cancer cells expressing SALL4 were tested as potential cancer therapeutic agents. A 12amino-acid peptide that disrupts the interaction between SALL4 and the NuRD complex comprising HDAC1 and HDAC2 was tested in AML and HCC. The peptide disrupted the interaction between SALL4 and HDAC, which blocked the NuRD-mediated SALL4 repression function $[155,174]$. Similarly, another peptide, known as PEN-FFW, was recently designed to target SALL4 in HCC cell lines. The peptide disrupted the SALL4-NuRD interaction via the blocking of the SALL4 interaction with RBBp4, specifically inhibiting the transcription-repressor function of SALL4. Treatment of HCC cells with the PEN-FFW 
peptide induced apoptosis, enhanced cell adhesion, and dramatically inhibited xenograft tumor growth [183]. The use of miRNAs targeting SALL4-associated HCC has also been proposed. Let-7/miR-98-induced SALL4 depletion decreased the expression of MMP2/9, Fibronectin, $n$-cadherin, and increased E-cadherin, which correlated with reduced migration/invasion and EMT in an HCC in vivo cancer model [100].

Alternative strategies are the use of drugs that can induce the degradation of SALL4. Small immunomodulatory drugs (IMiDs), such as thalidomide and derivatives, induce ubiquitination and the proteasomal degradation of zinc finger transcription factors. The mechanism involves recruiting $\mathrm{C} 2 \mathrm{H} 2$ zinc finger $(\mathrm{ZnF})$ domains to Cereblon ( $\mathrm{CRBN})$, the substrate receptor of the CRL4CRBN E3 ubiquitin ligase [184]. Thalidomide induced the robust degradation of SALL4 in the neuroblastoma (Kelly and SK-N-DZ) cell lines and the MM1 multiple myeloma cell line [185]. However, because of the critical role of SALL4 in limb development, treatment with thalidomide or analogous drugs during pregnancy could contribute to severe birth developmental abnormalities [17,185-187].

Studies on the reestablishment of the SALL tumor suppressor function have focused on demethylating agents' potential use. As indicated previously, SALL1, SALL2, and SALL3 hypermethylation are associated with bad prognosis in several cancers [54,55,92-97], and the epigenetic silencing of SALL2 confers tamoxifen resistance in breast cancer [54]. Treatment with 5-Aza-dC, a DNMT inhibitor, increased the sensitivity of SALL2 hypermethylated breast cancer to tamoxifen therapy in vitro and in vivo [54]. This result suggests that treatment with DNMT inhibitors might overcome tamoxifen resistance in breast cancer. However, co-therapy, including both a DNMT inhibitor and tamoxifen, might be an appropriate therapy for a subset of patients with breast cancer. In addition, Histone deacetylase inhibitors, including TSA (Class I and II inhibitor), Panobinostat (Pan-HDAC inhibitor), Vorinostat/SAHA (class I and II inhibitor), and Chidamide (class I inhibitor), also upregulated SALL2 in Jurkat T cells by a mechanism involving the recruitment of Sp1 and p300 to the P2 promoter [51].

Additional therapeutic strategies to restore tumor suppressor function could be related to the modulation of SALL1 or SALL2 protein levels by altering their ubiquitylation and subsequent proteasome degradation, or by inhibiting still unknown negative regulators of the transcription factor expression. Thus, efforts should also focus on identifying novel SALL regulators and partners.

\section{Concluding Remarks/Future Perspectives}

Increasing evidence shows an association between SALL family members with human cancers. Consistently, SALL4 acts as an oncogene; however, SALL1-3 play dual roles, depending on the cancer context and disease stage. Still, most studies support the tumor suppressor role of SALL1 and SALL2.

As expected with regard to the essential role of transcription factors in gene expression regulation, all SALLs directly or indirectly impact the hallmarks of cancer, including cell proliferation, cell migration, and cell survival. An analysis of the current literature highlights some common signaling pathways between SALL members such as PI3K/Akt and Wnt/ $\beta$-catenin and common target genes such as PTEN, CCDN1, c-MYC, VIM, and $C D H 1$. SALL proteins interact with specific protein partners to perform their functions; however, as indicated here, some partners are shared among family members. Examples are $\beta$-catenin, a partner of SALL1 and SALL4, and DNMT3, a partner of SALL3 and SALL4. In addition, all four SALLs interact with SOX2 in the stemness context [63,65-67], and with the $\mathrm{NuRD}$ complex that is associated with transcriptional repression activities $[5,28,32,34,36]$.

According to these few examples of shared signaling pathways and interactors related to the function of SALL proteins, genetic analysis of specific cancer types should consider all the family members. Specific SALLs might act oppositely, activating or repressing the same pathway, inducing or repressing the target gene. In addition, changes in expression of a particular SALL member, the presence of cancer-related isoforms, or specific mutations might affect the relative availability of shared protein partners and consequences as they 
could compete for interaction. Thus, the expression levels of each SALL family member and the pattern of interactors expressed in specific cells might influence cellular outcomes. These aspects are relevant as deregulated SALL1-4 have been reported in at least 11 cancer types analyzed in this review (Figure 3, Table 2).

Current literature indicates that SALL1 and SALL2 might have a dual role in cancer. A recent study using a database search and a literature annotation of 12 main cancers identified genes with oncogenic and tumor suppressor functions, which are called double agents [188]. Most of them encoded transcription factors or kinases and exhibited dual biological functions. Still, double agents mainly function as tumor suppressors in normal tissues. The dual role of SALL1 and SALL2 in cancer might relate to the expression of specific isoforms, the cancer stage, and the context (primary tumor versus metastasis), and/or the presence of particular partners. As an example of this, unlike its proposed tumor suppressor role in several cancer types, SALL2 acts as a cancer-promoting factor in GBM. In this context, SALL2 interacts with SOX2, and this interaction may lead to the binding of SALL2 to DNA elements (AT-rich) different from the SALL2 consensus sequence (GC-rich) [6,65], likely explaining its oncogenic role in GBM.

Another significant finding is the common epigenetic regulation of SALL genes and the association of epigenetic marks with patient prognosis. In general, the hypermethylation of SALL1-3 is associated with a bad prognosis in several cancers. Relevant for cancer therapeutics is that the demethylating agent 5-azacytidine increases SALL1 and SALL2 expression and is associated with a better prognosis. This evidence suggests that the $S A L L$ status is a valuable tool for predicting the response to chemotherapeutic drugs and other cancer treatments in various malignancies $[54,55,92,94-97,145,168,181,189]$. On the contrary, SALL4 promoter hypomethylation and miRNAs-dependent SALL4 regulation are common events in several cancer types [98-100]. Likewise, studies indicate that the oncogenic function of SALL4 and the tumor suppressor function of SALL1 greatly rely on the recruitment of the NuRD complex. Targeting the SALL4/NuRD interaction holds great potential for cancer treatment (see the section above on Targeting SALLs for cancer therapy). Although SALL1 is frequently epigenetically inactivated, it would be interesting to investigate the existence of mutations that impair its association with NuRD. Future studies should continue to focus on identifying the subunits of NuRD and target genes recruited by different SALL proteins in cancer.

Thus, efforts should pursue the identification of novel SALL regulators, partners, and targets. Additional mechanistic and comprehensive studies, including more than one SALL protein in similar cancer contexts, are required to understand the significance of SALLs alterations in cancer. In this regard, a recent article used the TCGA pan-cancer data and NCI-60 database to conduct a comprehensive analysis of SALL genes. The study suggests that SALLs associate with immune infiltrate subtypes, with a close association between different degrees of stromal and immune cell infiltration. Furthermore, it supports the idea that SALLs are related to cancer cell resistance [164]. However, further functional studies of $S A L L$ genes are required to confirm these findings.

Author Contributions: Conceptualization, C.Á., A.Q. and R.P.; investigation and artwork, C.Á., A.Q., E.R., D.B.-R. and R.P.; resources, R.P. and A.F.C.; writing—original draft preparation, R.P., C.Á. and A.Q.; writing-review and editing, C.Á., A.Q., E.R., D.B.-R., R.P. and A.F.C.; supervision, R.P. and A.F.C.; funding acquisition, R.P. and A.F.C. All authors have read and agreed to the published version of the manuscript.

Funding: Fondecyt Grant No. 1191172 to R.P., Fondecyt Grant No. 1201215 to A.F.C., PhD Fellowship 21181183 to A.Q., and PhD Fellowship 21181438 to C.Á.

Conflicts of Interest: The authors declare no conflict of interest. 


\section{References}

1. De Celis, J.F.; Barrio, R. Regulation and function of Spalt proteins during animal development. Int. J. Dev. Biol. 2009, 53, 1385-1398. [CrossRef]

2. Sweetman, D.; Munsterberg, A. The vertebrate spalt genes in development and disease. Dev. Biol. 2006, 293, 285-293. [CrossRef]

3. Lorente-Sorolla, J.; Truchado-Garcia, M.; Perry, K.J.; Henry, J.Q.; Grande, C. Molecular, phylogenetic and developmental analyses of Sall proteins in bilaterians. EvoDevo 2018, 9, 9. [CrossRef] [PubMed]

4. Hermosilla, V.; Hepp, M.I.; Escobar, D.; Farkas, C.; Riffo, E.N.; Castro, A.F.; Pincheira, R. Developmental SALL2 transcription factor: A new player in cancer. Carcinogenesis 2017, 38, 680-690. [CrossRef]

5. Lauberth, S.; Rauchman, M. A Conserved 12-Amino Acid Motif in Sall1 Recruits the Nucleosome Remodeling and Deacetylase Corepressor Complex. J. Biol. Chem. 2006, 281, 23922-23931. [CrossRef]

6. Farkas, C.; Quiroz, A.; Alvarez, C.; Hermosilla, V.; Aylwin, C.F.; Lomniczi, A.; Castro, A.F.; Hepp, M.I.; Pincheira, R. Characterization of SALL2 Gene Isoforms and Targets Across Cell Types Reveals Highly Conserved Networks. Front. Genet. 2021, 12, 1-15. [CrossRef]

7. Kohlhase, J.; Schuh, R.; Dowe, G.; Kühnlein, R.P.; Jäckle, H.; Schroeder, B.; Schulz-Schaeffer, W.; Kretzschmar, H.A.; Köhler, A.; Müller, U.; et al. Isolation, Characterization, and Organ-Specific Expression of Two Novel Human Zinc Finger Genes Related to theDrosophilaGenespalt. Genomics 1996, 38, 291-298. [CrossRef]

8. Ma, Y.; Cui, W.; Yang, J.; Qu, J.; Di, C.; Amin, H.M.; Lai, R.; Ritz, J.; Krause, D.S.; Chai, L. SALL4, a novel oncogene, is constitutively expressed in human acute myeloid leukemia (AML) and induces AML in transgenic mice. Blood 2006, 108, 2726-2735. [CrossRef]

9. Salman, H.; Shuai, X.; Nguyen-Lefebvre, A.T.; Giri, B.; Ren, M.; Rauchman, M.; Robbins, L.; Hou, W.; Korkaya, H.; Ma, Y. SALL1 expression in acute myeloid leukemia. Oncotarget 2018, 9, 7442-7452. [CrossRef]

10. Böhm, J.; Sustmann, C.; Wilhelm, C.; Kohlhase, J. SALL4 is directly activated by TCF/LEF in the canonical Wnt signaling pathway. Biochem. Biophys. Res. Commun. 2006, 348, 898-907. [CrossRef]

11. Nicolè, L.; Sanavia, T.; Veronese, N.; Cappellesso, R.; Luchini, C.; Dabrilli, P.; Fassina, A. Oncofetal gene SALL4 and prognosis in cancer: A systematic review with meta-analysis. Oncotarget 2017, 8, 22968-22979. [CrossRef]

12. Tatetsu, H.; Kong, N.R.; Chong, G.; Amabile, G.; Tenen, D.G.; Chai, L. SALL4, the missing link between stem cells, development and cancer. Gene 2016, 584, 111-119. [CrossRef]

13. Zhang, X.; Yuan, X.; Zhu, W.; Qian, H.; Xu, W. SALL4: An emerging cancer biomarker and target. Cancer Lett. 2015 , 357, 55-62. [CrossRef]

14. Sung, C.K.; Yim, H. Roles of SALL2 in tumorigenesis. Arch. Pharmacal Res. 2016, 40, 146-151. [CrossRef] [PubMed]

15. Sung, C.K.; Yim, H. The tumor suppressor protein p150Sal2 in carcinogenesis. Tumor Biol. 2015, 36, 489-494. [CrossRef]

16. Kawakami, Y.; Uchiyama, Y.; Esteban, C.R.; Inenaga, T.; Koyano-Nakagawa, N.; Kawakami, H.; Marti, M.; Kmita, M.; MonaghanNichols, P.; Nishinakamura, R.; et al. Sall genes regulate region-specific morphogenesis in the mouse limb by modulating Hox activities. Development 2009, 136, 585-594. [CrossRef]

17. Kohlhase, J.; Heinrich, M.; Schubert, L.; Liebers, M.; Kispert, A.; Laccone, F.; Turnpenny, P.; Winter, R.M.; Reardon, W. Okihiro syndrome is caused by SALL4 mutations. Hum. Mol. Genet. 2002, 11, 2979-2987. [CrossRef]

18. Kelberman, D.; Islam, L.; Lakowski, J.; Bacchelli, C.; Chanudet, E.; Lescai, F.; Patel, A.; Stupka, E.; Buck, A.; Wolf, S.; et al. Mutation of SALL2 causes recessive ocular coloboma in humans and mice. Hum. Mol. Genet. 2014, 23, 2511-2526. [CrossRef]

19. Dostal, A.; Nemeckova, J.; Gaillyova, R. The 18q deletion syndrome and analysis of the critical region for orofacial cleft at $18 \mathrm{q} 22.3$. J. Cranio-Maxillofac. Surg. 2009, 37, 272-275. [CrossRef]

20. Kiefer, S.M.; Ohlemiller, K.K.; Yang, J.; McDill, B.W.; Kohlhase, J.; Rauchman, M. Expression of a truncated Sall1 transcriptional repressor is responsible for Townes-Brocks syndrome birth defects. Hum. Mol. Genet. 2003, 12, 2221-2227. [CrossRef]

21. Parrish, M.; Ott, T.; Lance-Jones, C.; Schuetz, G.; Schwaeger-Nickolenko, A.; Monaghan, A.P. Loss of the Sall3 Gene Leads to Palate Deficiency, Abnormalities in Cranial Nerves, and Perinatal Lethality. Mol. Cell. Biol. 2004, 24, 7102-7112. [CrossRef]

22. Warren, M.; Wang, W.; Spiden, S.; Chen-Murchie, D.; Tannahill, D.; Steel, K.P.; Bradley, A. ASall4 mutant mouse model useful for studying the role ofSall4 in early embryonic development and organogenesis. Genes 2007, 45, 51-58. [CrossRef]

23. Sato, A.; Matsumoto, Y.; Koide, U.; Kataoka, Y.; Yoshida, N.; Yokota, T.; Asashima, M.; Nishinakamura, R. Zinc Finger Protein Sall2 Is Not Essential for Embryonic and Kidney Development. Mol. Cell. Biol. 2003, 23, 62-69. [CrossRef]

24. Böhm, J.; Buck, A.; Borozdin, W.; Mannan, A.U.; Matysiak-Scholze, U.; Adham, I.; Schulz-Schaeffer, W.; Floss, T.; Wurst, W.; Kohlhase, J.; et al. Sall1, Sall2, and Sall4 Are Required for Neural Tube Closure in Mice. Am. J. Pathol. 2008, 173, $1455-1463$. [CrossRef]

25. Chai, L. The role of HSAL (SALL) genes in proliferation and differentiation in normal hematopoiesis and leukemogenesis. Transfusion 2011, 51, 87S-93S. [CrossRef]

26. Hermosilla, V.; Salgado, G.; Riffo, E.; Escobar, D.; Hepp, M.; Farkas, C.; Galindo, M.; Morín, V.; García-Robles, M.A.; Castro, A.F.; et al. SALL2 represses cyclins D1 and E1 expression and restrains G1/S cell cycle transition and cancer-related phenotypes. Mol. Oncol. 2018, 12, 1026-1046. [CrossRef]

27. Basta, J.M.; Singh, A.P.; Robbins, L.; Stout, L.; Pherson, M.; Rauchman, M. The core SWI/SNF catalytic subunit Brg1 regulates nephron progenitor cell proliferation and differentiation. Dev. Biol. 2020, 464, 176-187. [CrossRef]

28. Basta, J.M.; Robbins, L.; Denner, D.R.; Kolar, G.R.; Rauchman, M. Sall1-NuRD interaction regulates multipotent nephron progenitors and is required for loop of Henle formation. Development 2017, 144, 3080-3094. [CrossRef] 
29. Basta, J.; Rauchman, M. The Nucleosome Remodeling and Deacetylase (NuRD) Complex in Development and Disease. Transl. Res. 2015, 165, 36-47. [CrossRef]

30. Tahara, N.; Kawakami, H.; Chen, K.Q.; Anderson, A.; Peterson, M.Y.; Gong, W.; Shah, P.; Hayashi, S.; Nishinakamura, R.; Nakagawa, Y.; et al. Sall4 regulates neuromesodermal progenitors and their descendants during body elongation in mouse embryos. Development 2019, 146,1-10. [CrossRef] [PubMed]

31. Lai, A.Y.; Wade, P.A. Cancer biology and NuRD: A multifaceted chromatin remodelling complex. Nat. Rev. Cancer 2011, 11, 588-596. [CrossRef]

32. Lu, J.; Jeong, H.; Kong, N.; Yang, Y.; Carroll, J.; Luo, H.R.; Silberstein, L.E.; Ma, Y.; Chai, L. Stem Cell Factor SALL4 Represses the Transcriptions of PTEN and SALL1 through an Epigenetic Repressor Complex. PLoS ONE 2009, 4, e5577. [CrossRef]

33. Chan, A.-L.; La, H.M.; Legrand, J.; Mäkelä, J.-A.; Eichenlaub, M.; De Seram, M.; Ramialison, M.; Hobbs, R.M. Germline Stem Cell Activity Is Sustained by SALL4-Dependent Silencing of Distinct Tumor Suppressor Genes. Stem Cell Rep. 2017, 9, $956-971$. [CrossRef]

34. Miller, A.; Ralser, M.; Kloet, S.; Loos, R.; Nishinakamura, R.; Bertone, P.; Vermeulen, M.; Hendrich, B. Sall4 controls differentiation of pluripotent cells independently of the Nucleosome Remodelling and Deacetylation (NuRD) complex. Development 2016, 143, 3074-3084. [CrossRef]

35. Lauberth, S.M.; Bilyeu, A.C.; Firulli, B.A.; Kroll, K.L.; Rauchman, M. A Phosphomimetic Mutation in the Sall1 Repression Motif Disrupts Recruitment of the Nucleosome Remodeling and Deacetylase Complex and Repression of Gbx2. J. Biol. Chem. 2007, 282, 34858-34868. [CrossRef]

36. Ma, C.; Wang, F.; Han, B.; Zhong, X.; Si, F.; Ye, J.; Hsueh, E.C.; Robbins, L.; Kiefer, S.M.; Zhang, Y.; et al. SALL1 functions as a tumor suppressor in breast cancer by regulating cancer cell senescence and metastasis through the NuRD complex. Mol. Cancer 2018, 17, 1-21. [CrossRef]

37. Lamouille, S.; Xu, J.; Derynck, R. Molecular mechanisms of epithelial-mesenchymal transition. Nat. Rev. Mol. Cell Biol. 2014, 15, 178-196. [CrossRef]

38. Li, D.; Tian, Y.; Ma, Y.; Benjamin, T. p150 Sal2 Is a p53-Independent Regulator of p21 WAF1/CIP. Mol. Cell. Biol. 2004, 24, 3885-3893. [CrossRef]

39. Wu, Z.; Cheng, K.; Shi, L.; Li, Z.; Negi, H.; Gao, G.; Kamle, S.; Li, D. Sal-like protein 2 upregulates p16 expression through a proximal promoter element. Cancer Sci. 2015, 106, 253-261. [CrossRef]

40. Miao, F.; Zhang, X.; Cao, Y.; Wang, Y.; Zhang, X. Effect of siRNA-silencing of SALL2 gene on growth, migration and invasion of human ovarian carcinoma A2780 cells. BMC Cancer 2017, 17, 838. [CrossRef]

41. Chen, M.; Li, L.; Zheng, P. SALL4 promotes the tumorigenicity of cervical cancer cells through activation of the Wnt/ $\beta$-catenin pathway viaCTNNB1. Cancer Sci. 2019, 110, 2794-2805. [CrossRef]

42. He, J.; Zhou, M.; Chen, X.; Yue, D.; Yang, L.; Qin, G.; Zhang, Z.; Gao, Q.; Wang, D.; Zhang, C.; et al. Inhibition of SALL4 reduces tumorigenicity involving epithelial-mesenchymal transition via Wnt/ $\beta$-catenin pathway in esophageal squamous cell carcinoma. J. Exp. Clin. Cancer Res. 2016, 35, 1-13. [CrossRef]

43. Li, J.; Zhang, Y.; Tao, X.; You, Q.; Tao, Z.; He, Z.; Ou, J. Knockdown of SALL4 inhibits the proliferation, migration, and invasion of human lung cancer cells in vivo and in vitro. Ann. Transl. Med. 2020, 8, 1678. [CrossRef] [PubMed]

44. Liu, C.; Wu, H.; Li, Y.; Shen, L.; Yu, R.; Yin, H.; Sun, T.; Sun, C.; Zhou, Y.; Du, Z. SALL4 suppresses PTEN expression to promote glioma cell proliferation via PI3K/AKT signaling pathway. J. Neuro-Oncol. 2017, 135, 263-272. [CrossRef]

45. Liu, C.; Yao, F.; Mao, X.; Li, W.; Chen, H. Effect of SALL4 on the Proliferation, Invasion and Apoptosis of Breast Cancer Cells. Technol. Cancer Res. Treat. 2020, 19, 1-10. [CrossRef]

46. Sung, C.K.; Yim, H.; Gu, H.; Li, D.; Andrews, E.; Duraisamy, S.; Li, C.; Drapkin, R.; Benjamin, T. The Polyoma Virus Large T Binding Protein p150 Is a Transcriptional Repressor of c-MYC. PLoS ONE 2012, 7, e46486. [CrossRef]

47. Sato, A.; Kishida, S.; Tanaka, T.; Kikuchi, A.; Kodama, T.; Asashima, M.; Nishinakamura, R. Sall1, a causative gene for TownesBrocks syndrome, enhances the canonical Wnt signaling by localizing to heterochromatin. Biochem. Biophys. Res. Commun. 2004, 319, 103-113. [CrossRef]

48. Yang, J.; Chai, L.; Gao, C.; Fowles, T.C.; Alipio, Z.; Dang, H.; Xu, D.; Fink, L.M.; Ward, D.C.; Ma, Y. SALL4 is a key regulator of survival and apoptosis in human leukemic cells. Blood 2008, 112, 805-813. [CrossRef]

49. Gu, H.; Li, D.; Sung, C.K.; Yim, H.; Troke, P.; Benjamin, T. DNA-binding and regulatory properties of the transcription factor and putative tumor suppressor p150Sal2. Biochim. Biophys. Acta (BBA)-Bioenerg. 2011, 1809, 276-283. [CrossRef]

50. Escobar, D.; Hepp, M.; Farkas, C.; Campos, T.M.C.; Sodir, N.M.; Morales, M.M.; Alvarez, C.; Swigart, L.B.; Evan, G.I.; Gutierrez, J.; et al. Sall2 is required for proapoptotic Noxa expression and genotoxic stress-induced apoptosis by doxorubicin. Cell Death Dis. 2015, 6, e1816. [CrossRef]

51. Hepp, M.I.; Escobar, D.; Farkas, C.; Hermosilla, V.; Álvarez, C.; Amigo, R.; Gutiérrez, J.L.; Castro, A.F.; Pincheira, R. A Trichostatin A (TSA)/Sp1-mediated mechanism for the regulation of SALL2 tumor suppressor in Jurkat T cells. Biochim. Biophys. Acta (BBA)-Bioenerg. 2018, 1861, 623-636. [CrossRef]

52. Hopkins, B.D.; Hodakoski, C.; Barrows, D.; Mense, S.M.; Parsons, R.E. PTEN function: The long and the short of it. Trends Biochem. Sci. 2014, 39, 183-190. [CrossRef]

53. Deng, G.; Zhu, L.; Huang, F.; Nie, W.; Huang, W.; Xu, H.; Zheng, S.; Yi, Z.; Wan, T. Knockdown of Sall4 inhibits intrahepatic cholangiocarcinoma cell migration and invasion in ICC-9810 cells. OncoTargets Ther. 2016, 9, 5297-5305. [CrossRef] 
54. Ye, L.; Lin, C.; Wang, X.; Li, Q.; Li, Y.; Wang, M.; Zhao, Z.; Wu, X.; Shi, D.; Xiao, Y.; et al. Epigenetic silencing of SALL 2 confers tamoxifen resistance in breast cancer. EMBO Mol. Med. 2019, 11, e10638. [CrossRef]

55. Luo, J.; Wang, W.; Tang, Y.; Zhou, D.; Gao, Y.; Zhang, Q.; Zhou, X.; Zhu, H.; Xing, L.; Yu, J. mRNA and methylation profiling of radioresistant esophageal cancer cells: The involvement of Sall2 in acquired aggressive phenotypes. J. Cancer 2017, 8, 646-656. [CrossRef]

56. Yang, J.; Aguila, J.R.; Alipio, Z.; Lai, R.; Fink, L.M.; Ma, Y. Enhanced self-renewal of hematopoietic stem/progenitor cells mediated by the stem cell gene Sall4. J. Hematol. Oncol. 2011, 4, 38. [CrossRef] [PubMed]

57. Fukuda, S.; Hoggatt, J.; Singh, P.; Abe, M.; Speth, J.; Hu, P.; Conway, E.; Nucifora, G.; Yamaguchi, S.; Pelus, L.M. Survivin modulates genes with divergent molecular functions and regulates proliferation of hematopoietic stem cells through Evi-1. Leukemia 2014, 29, 433-440. [CrossRef]

58. Zhou, Q.; Guo, Y.; Zheng, B.; Shao, B.; Jiang, M.; Wang, G.; Zhou, T.; Wang, L.; Zhou, Z.; Guo, X.; et al. Establishment of a proteome profile and identification of molecular markers for mouse spermatogonial stem cells. J. Cell. Mol. Med. 2014, 19, 521-534. [CrossRef] [PubMed]

59. Morita, Y.; Andersen, P.; Hotta, A.; Tsukahara, Y.; Sasagawa, N.; Hayashida, N.; Koga, C.; Nishikawa, M.; Saga, Y.; Evans, S.M.; et al. Sall1 transiently marks undifferentiated heart precursors and regulates their fate. J. Mol. Cell. Cardiol. 2016, 92, 158-162. [CrossRef] [PubMed]

60. Osafune, K.; Takasato, M.; Kispert, A.; Asashima, M.; Nishinakamura, R. Identification of multipotent progenitors in the embryonic mouse kidney by a novel colony-forming assay. Development 2006, 133, 151-161. [CrossRef] [PubMed]

61. Lin, Y.; Xiao, Y.; Lin, C.; Zhang, Q.; Zhang, S.; Pei, F.; Liu, H.; Chen, Z. SALL1 regulates commitment of odontoblast lineages by interacting with RUNX2 to remodel open chromatin regions. Stem Cells 2020, 39, 196-209. [CrossRef]

62. Hobbs, R.; Fagoonee, S.; Papa, A.; Webster, K.; Altruda, F.; Nishinakamura, R.; Chai, L.; Pandolfi, P.P. Functional Antagonism between Sall4 and Plzf Defines Germline Progenitors. Cell Stem Cell 2012, 10, 284-298. [CrossRef] [PubMed]

63. Yang, J.; Gao, C.; Chai, L.; Ma, Y. A Novel SALL4/OCT4 Transcriptional Feedback Network for Pluripotency of Embryonic Stem Cells. PLoS ONE 2010, 5, e10766. [CrossRef]

64. Pantier, R.; Chhatbar, K.; Quante, T.; Skourti-Stathaki, K.; Cholewa-Waclaw, J.; Alston, G.; Alexander-Howden, B.; Lee, H.Y.; Cook, A.G.; Spruijt, C.G.; et al. SALL4 controls cell fate in response to DNA base composition. Mol. Cell 2021, 81, 845-858.e8. [CrossRef]

65. Suvà, M.L.; Rheinbay, E.; Gillespie, S.M.; Patel, A.P.; Wakimoto, H.; Rabkin, S.D.; Riggi, N.; Chi, A.S.; Cahill, D.P.; Nahed, B.V.; et al. Reconstructing and Reprogramming the Tumor-Propagating Potential of Glioblastoma Stem-like Cells. Cell 2014, 157, 580-594. [CrossRef]

66. Karantzali, E.; Lekakis, V.; Ioannou, M.; Hadjimichael, C.; Papamatheakis, J.; Kretsovali, A. Sall1 Regulates Embryonic Stem Cell Differentiation in Association with Nanog. J. Biol. Chem. 2011, 286, 1037-1045. [CrossRef]

67. Quevedo, M.; Meert, L.; Dekker, M.R.; Dekkers, D.H.W.; Brandsma, J.H.; Berg, D.L.C.V.D.; Ozgür, Z.; Van Ijcken, W.F.J.; Demmers, J.; Fornerod, M.; et al. Mediator complex interaction partners organize the transcriptional network that defines neural stem cells. Nat. Commun. 2019, 10, 1-15. [CrossRef]

68. Argos, M.; Kibriya, M.G.; Jasmine, F.; Olopade, O.I.; Su, T.; Hibshoosh, H.; Ahsan, H. Genomewide scan for loss of heterozygosity and chromosomal amplification in breast carcinoma using single-nucleotide polymorphism arrays. Cancer Genet. Cytogenet. 2008, 182, 69-74. [CrossRef]

69. Mathew, R.; Arora, S.; Mathur, M.; Ralhan, R.; Chattopadhyay, T.K. Esophageal squamous cell carcinomas with DNA replication errors (RER +) are associated with p16/pRb loss and wild-type p53. J. Cancer Res. Clin. Oncol. 2001, 127, 603-612. [CrossRef]

70. Chang, W.Y.; Cairns, P.; Schoenberg, M.P.; Polascik, T.J.; Sidransky, D. Novel suppressor loci on chromosome 14q in primary bladder cancer. Cancer Res. 1995, 55, 3246-3249.

71. Abujiang, P.; Mori, T.J.; Takahashi, T.; Tanaka, F.; Kasyu, I.; Hitomi, S.; Hiai, H. Loss of heterozygosity (LOH) at 17q and 14q in human lung cancers. Oncogene 1998, 17, 3029-3033. [CrossRef]

72. Al-Mulla, F.; Alfadhli, S.; Al-Hakim, A.H.; Going, J.J.; Bitar, M.S. Metastatic recurrence of early-stage colorectal cancer is linked to loss of heterozygosity on chromosomes 4 and 14q. J. Clin. Pathol. 2006, 59, 624-630. [CrossRef]

73. Beder, L.B.; Gunduz, M.; Ouchida, M.; Fukushima, K.; Gunduz, E.; Ito, S.; Sakai, A.; Nagai, N.; Nishizaki, K.; Shimizu, K. Genome-Wide Analyses on Loss of Heterozygosity in Head and Neck Squamous Cell Carcinomas. Lab. Investig. 2003, 83, 99-105. [CrossRef]

74. Lee, D.J.; Koch, W.M.; Yoo, G.; Lango, M.; Reed, A.; Califano, J.; Brennan, J.A.; Westra, W.H.; Zahurak, M.; Sidransky, D. Impact of chromosome 14q loss on survival in primary head and neck squamous cell carcinoma. Clin. Cancer Res. 1997, 3, 501-505.

75. Pehlivan, D.; Gunduz, E.; Gunduz, M.; Nagatsuka, H.; Beder, L.B.; Cengiz, B.; Rivera, R.S.; Fukushima, K.; Palanduz, S.; Ozturk, S.; et al. Loss of heterozygosity at chromosome $14 \mathrm{q}$ is associated with poor prognosis in head and neck squamous cell carcinomas. $J$. Cancer Res. Clin. Oncol. 2008, 134, 1267-1276. [CrossRef]

76. Nishizuka, S.; Tamura, G.; Terashima, M.; Satodate, R. Loss of heterozygosity during the development and progression of differentiated adenocarcinoma of the stomach. J. Pathol. 1998, 185, 38-43. [CrossRef]

77. Takebayashi, S.; Hickson, A.; Ogawa, T.; Jung, K.-Y.; Mineta, H.; Ueda, Y.; Grénman, R.; Fisher, S.G.; Carey, T.E. Loss of chromosome arm 18q with tumor progression in head and neck squamous cancer. Genes Chromosomes Cancer 2004, 41, 145-154. [CrossRef] 
78. Jen, J.; Kim, H.; Piantadosi, S.; Liu, Z.-F.; Levitt, R.C.; Sistonen, P.; Kinzler, K.W.; Vogelstein, B.; Hamilton, S.R. Allelic Loss of Chromosome 18q and Prognosis in Colorectal Cancer. N. Engl. J. Med. 1994, 331, 213-221. [CrossRef]

79. Savelieva, E.; Belair, C.D.; Newton, M.A.; Devries, S.; Gray, J.W.; Waldman, F.; Reznikoff, C.A. 20q gain associates with immortalization: 20q13.2 amplification correlates with genome instability in human papillomavirus 16 E7 transformed human uroepithelial cells. Oncogene 1997, 14, 551-560. [CrossRef]

80. Werner, M.; Mattis, A.; Aubele, M.; Cummings, M.; Zitzelsberger, H.; Hutzler, P.; Höfler, H. 20q13.2 Amplification in intraductal hyperplasia adjacent to in situ and invasive ductal carcinoma of the breast. Virchows Arch. 1999, 435, 469-472. [CrossRef]

81. Huang, H.-N.; Huang, W.-C.; Lin, C.-H.; Chiang, Y.-C.; Huang, H.-Y.; Kuo, K.-T. Chromosome 20q13.2 ZNF217 locus amplification correlates with decreased E-cadherin expression in ovarian clear cell carcinoma with PI3K-Akt pathway alterations. Hum. Pathol. 2014, 45, 2318-2325. [CrossRef]

82. Briand-Suleau, A.; Martinovic, J.; Tosca, L.; Tou, B.; Brisset, S.; Bouligand, J.; Delattre, V.; Giurgea, I.; Bachir, J.; Folliot, P.; et al. SALL4 and NFATC2: Two major actors of interstitial 20q13.2 duplication. Eur. J. Med. Genet. 2014, 57, 174-180. [CrossRef] [PubMed]

83. Okamoto, A.; Sehouli, J.; Yanaihara, N.; Hirata, Y.; Braicu, I.; Kim, B.-G.; Takakura, S.; Saito, M.; Yanagida, S.; Takenaka, M.; et al. Somatic Copy Number Alterations Associated with Japanese or Endometriosis in Ovarian Clear Cell Adenocarcinoma. PLoS ONE 2015, 10, e0116977. [CrossRef] [PubMed]

84. Koh, H.M.; Jang, B.G.; Hyun, C.L.; Kim, Y.S.; Hyun, J.W.; Chang, W.Y.; Maeng, Y.H. Aurora Kinase A Is a Prognostic Marker in Colorectal Adenocarcinoma. J. Pathol. Transl. Med. 2017, 51, 32-39. [CrossRef]

85. Morikawa, A.; Hayashi, T.; Kobayashi, M.; Kato, Y.; Shirahige, K.; Itoh, T.; Urashima, M.; Okamoto, A.; Akiyama, T. Somatic copy number alterations have prognostic impact in patients with ovarian clear cell carcinoma. Oncol. Rep. 2018, 40, 309-318. [CrossRef]

86. Sung, C.K.; Dahl, J.; Yim, H.; Rodig, S.; Benjamin, A.T.L. Transcriptional and post-translational regulation of the quiescence factor and putative tumor suppressor p150Sal2. FASEB J. 2011, 25, 1275-1283. [CrossRef]

87. Ma, Y.; Li, D.; Chai, L.; Luciani, A.M.; Ford, D.; Morgan, J.; Maizel, A.L. Cloning and Characterization of Two Promoters for the Human HSAL2 Gene and Their Transcriptional Repression by the Wilms Tumor Suppressor Gene Product. J. Biol. Chem. 2001, 276, 48223-48230. [CrossRef]

88. Farkas, C.; Martins, C.P.; Escobar, D.; Hepp, M.I.; Donner, D.B.; Castro, A.F.; Evan, G.; Gutiérrez, J.L.; Warren, R.; Pincheira, R. Wild Type p53 Transcriptionally Represses the SALL2 Transcription Factor under Genotoxic Stress. PLoS ONE 2013, 8, e73817. [CrossRef]

89. Pecce, V.; Verrienti, A.; Fiscon, G.; Sponziello, M.; Conte, F.; Abballe, L.; Durante, C.; Farina, L.; Filetti, S.; Paci, P. The role of FOSL1 in stem-like cell reprogramming processes. Sci. Rep. 2021, 11, 1-11. [CrossRef]

90. Bard, J.D.; Gelebart, P.; Amin, H.M.; Young, L.C.; Ma, Y.; Lai, R. Signal transducer and activator of transcription 3 is a transcriptional factor regulating the gene expression ofSALL4. FASEB J. 2009, 23, 1405-1414. [CrossRef] [PubMed]

91. Fujii, Y.; Yoshihashi, K.; Suzuki, H.; Tsutsumi, S.; Mutoh, H.; Maeda, S.; Yamagata, Y.; Seto, Y.; Aburatani, H.; Hatakeyama, M. CDX1 confers intestinal phenotype on gastric epithelial cells via induction of stemness-associated reprogramming factors SALL4 and KLF5. Proc. Natl. Acad. Sci. USA 2012, 109, 20584-20589. [CrossRef]

92. Hill, V.K.; Hesson, L.B.; Dansranjavin, T.; Dallol, A.; Bieche, I.; Vacher, S.; Tommasi, S.; Dobbins, T.; Gentle, D.; Euhus, D.; et al. Identification of 5 novel genes methylated in breast and other epithelial cancers. Mol. Cancer 2010, 9, 51. [CrossRef]

93. Wang, C.; Pu, W.; Zhao, D.; Zhou, Y.; Lu, T.; Chen, S.; He, Z.; Feng, X.; Wang, Y.; Li, C.; et al. Identification of Hyper-Methylated Tumor Suppressor Genes-Based Diagnostic Panel for Esophageal Squamous Cell Carcinoma (ESCC) in a Chinese Han Population. Front. Genet. 2018, 9, 356. [CrossRef]

94. Imai, A.; Mochizuki, D.; Misawa, Y.; Nakagawa, T.; Endo, S.; Mima, M.; Yamada, S.; Kawasaki, H.; Kanazawa, T.; Misawa, K. SALL2 Is a Novel Prognostic Methylation Marker in Patients with Oral Squamous Carcinomas: Associations with SALL1 and SALL3 Methylation Status. DNA Cell Biol. 2019, 38, 678-687. [CrossRef] [PubMed]

95. Misawa, K.; Kanazawa, T.; Mochizuki, D.; Imai, A.; Mima, M.; Yamada, S.; Morita, K.; Misawa, Y.; Shinmura, K.; Mineta, H. Genes Located on 18q23 Are Epigenetic Markers and Have Prognostic Significance for Patients with Head and Neck Cancer. Cancers 2019, 11, 401. [CrossRef]

96. Misawa, K.; Mochizuki, D.; Imai, A.; Misawa, Y.; Endo, S.; Mima, M.; Kawasaki, H.; Carey, T.E.; Kanazawa, T. Epigenetic silencing of SALL3 is an independent predictor of poor survival in head and neck cancer. Clin. Epigenet. 2017, 9, 1-12. [CrossRef]

97. Misawa, K.; Misawa, Y.; Imai, A.; Mochizuki, D.; Endo, S.; Mima, M.; Ishikawa, R.; Kawasaki, H.; Yamatodani, T.; Kanazawa, T. Epigenetic modification of SALL1 as a novel biomarker for the prognosis of early stage head and neck cancer. J. Cancer 2018, 9 , 941-949. [CrossRef]

98. Lin, J.; Qian, J.; Yao, D.-M.; Qian, W.; Yang, J.; Wang, C.-Z.; Chai, H.-Y.; Ma, J.-C.; Deng, Z.-Q.; Li, Y.; et al. Aberrant hypomethylation of SALL4 gene in patients with myelodysplastic syndrome. Leuk. Res. 2013, 37, 71-75. [CrossRef]

99. Ma, J.-C.; Qian, J.; Lin, J.; Qian, W.; Yang, J.; Wang, C.-Z.; Chai, H.-Y.; Li, Y.; Chen, Q.; Qian, Z. Aberrant hypomethylation of SALL4 gene is associated with intermediate and poor karyotypes in acute myeloid leukemia. Clin. Biochem. 2013, 46, 304-307. [CrossRef]

100. Liu, J.; Sauer, M.A.; Hussein, S.G.; Yang, J.; Tenen, D.G.; Chai, L. SALL4 and microRNA: The Role of Let-7. Genes 2021, $12,1301$. [CrossRef] 
101. Yang, C.M.; Chiba, T.; Brill, B.; Delis, N.; von Manstein, V.; Vafaizadeh, V.; Oellerich, T.; Groner, B. Expression of the mi R-302/367 cluster in glioblastoma cells suppresses tumorigenic gene expression patterns and abolishes transformation related phenotypes. Int. J. Cancer 2015, 137, 2296-2309. [CrossRef]

102. Zhou, Y.; Liu, Y.; Hu, C.; Jiang, Y. MicroRNA-16 inhibits the proliferation, migration and invasion of glioma cells by targeting Sal-like protein 4. Int. J. Mol. Med. 2016, 38, 1768-1776. [CrossRef]

103. Chen, L.-P.; Zhang, N.-N.; Ren, X.-Q.; He, J.; Li, Y. miR-103/miR-195/miR-15b Regulate SALL4 and Inhibit Proliferation and Migration in Glioma. Molecules 2018, 23, 2938. [CrossRef]

104. He, J.; Zhang, W.; Zhou, Q.; Zhao, T.; Song, Y.; Chai, L.; Li, Y. Low-expression of microRNA-107 inhibits cell apoptosis in glioma by upregulation of SALL4. Int. J. Biochem. Cell Biol. 2013, 45, 1962-1973. [CrossRef]

105. Zhou, Y.; Peng, Y.; Liu, M.; Jiang, Y. MicroRNA-181b Inhibits Cellular Proliferation and Invasion of Glioma Cells via Targeting Sal-Like Protein 4. Oncol. Res. Featur. Preclin. Clin. Cancer Ther. 2017, 25, 947-957. [CrossRef]

106. Wang, M.; Qiu, R.; Gong, Z.; Zhao, X.; Wang, T.; Zhou, L.; Lu, W.; Shen, B.; Zhu, W.; Xu, W. miR-188-5p emerges as an oncomiRNA to promote gastric cancer cell proliferation and migration via upregulation of SALL4. J. Cell. Biochem. 2019, 120, 15027-15037. [CrossRef] [PubMed]

107. Jiang, X.; Wang, Z. miR-16 targets SALL4 to repress the proliferation and migration of gastric cancer. Oncol. Lett. 2018, 16, 3005-3012. [CrossRef]

108. Kondelova, A.; Alburquerque-González, B.; Vychytilova-Faltejskova, P.; García-Solano, J.; Prochazka, V.; Kala, Z.; Pérez, F.; Slaby, O.; Conesa-Zamora, P. miR-181a-2* expression is different amongst carcinomas from the colorectal serrated route. Mutagenesis 2020, 35, 233-241. [CrossRef] [PubMed]

109. Cheng, J.; Deng, R.; Zhang, P.; Wu, C.; Wu, K.; Shi, L.; Liu, X.; Bai, J.; Deng, M.; Shuai, X.; et al. miR-219-5p plays a tumor suppressive role in colon cancer by targeting oncogene Sall4. Oncol. Rep. 2015, 34, 1923-1932. [CrossRef]

110. Chang, S.; Sun, G.; Zhang, D.; Li, Q.; Qian, H. MiR-3622a-3p acts as a tumor suppressor in colorectal cancer by reducing stemness features and EMT through targeting spalt-like transcription factor 4. Cell Death Dis. 2020, 11, 1-19. [CrossRef] [PubMed]

111. Rahnama, M.A.; Movassaghpour, A.A.; Soleimani, M.; Atashi, A.; Anbarlou, A.; Asenjan, K.S. MicroRNA-15b target Sall4 and diminish in vitro UCB-derived HSCs expansion. EXCLI J. 2015, 14, 601-610. [CrossRef]

112. Melton, C.; Judson, R.L.; Blelloch, R. Opposing microRNA families regulate self-renewal in mouse embryonic stem cells. Nat. Cell Biol. 2010, 463, 621-626. [CrossRef]

113. Liu, X.; Cao, Y.; Zhang, Y.; Zhou, H.; Li, H. Regulatory effect of MiR103 on proliferation, EMT and invasion of oral squamous carcinoma cell through SALL4. Eur. Rev. Med. Pharmacol. Sci. 2019, 23, 9931-9938.

114. Yuan, J.H.; Li, W.X.; Hu, C.; Zhang, B. Upregulation of SNHG12 accelerates cell proliferation, migration, invasion and restrain cell apoptosis in breast cancer by enhancing regulating SALL4 expression via sponging miR-15a-5p. Neoplasma 2020, 67, 861-870. [CrossRef]

115. Chen, Y.; He, J.; Su, C.; Wang, H.; Chen, Y.; Guo, W.; Li, Y.; Ding, G. LINC00461 affects the survival of patients with renal cell carcinoma by acting as a competing endogenous RNA for microRNA-942. Oncol. Rep. 2019, 42, 1924-1934. [CrossRef] [PubMed]

116. Li, Z.; Zhao, S.; Wang, H.; Zhang, B.; Zhang, P. miR-4286 promotes prostate cancer progression via targeting the expression of SALL1. J. Gene Med. 2019, e3127. [CrossRef]

117. Xia, H.; Niu, Q.; Ding, Y.; Zhang, Z.; Yuan, J.; Jin, W. Long noncoding HOXA11-AS knockdown suppresses the progression of non-small cell lung cancer by regulating miR-3619-5p/SALL4 axis. J. Mol. Histol. 2021, 52, 729-740. [CrossRef]

118. Wang, Y.; Liu, N.; Li, M.-Y.; Du, M.-F. Long non-coding RNA ZEB2-AS1 regulates osteosarcoma progression by acting as a molecular sponge of miR-107 to modulate SALL4 expression. Am. J. Transl. Res. 2021, 13, 1140-1154.

119. Shi, D.-M.; Shi, X.-L.; Xing, K.-L.; Zhou, H.-X.; Lu, L.-L.; Wu, W.-Z. miR-296-5p suppresses stem cell potency of hepatocellular carcinoma cells via regulating Brg1/Sall4 axis. Cell. Signal. 2020, 72, 109650. [CrossRef]

120. Ma, Y.-S.; Liu, J.-B.; Lin, L.; Zhang, H.; Wu, J.-J.; Shi, Y.; Jia, C.-Y.; Zhang, D.-D.; Yu, F.; Wang, H.-M.; et al. Exosomal microRNA-15a from mesenchymal stem cells impedes hepatocellular carcinoma progression via downregulation of SALL4. Cell Death Discov. 2021, 7, 1-11. [CrossRef]

121. Misawa, K.; Misawa, Y.; Mima, M.; Yamada, S.; Imai, A.; Mochizuki, D.; Nakagawa, T.; Kurokawa, T.; Endo, S.; Kawasaki, H.; et al. Overexpression of Sal-like protein 4 in head and neck cancer: Epigenetic effects and clinical correlations. Cell. Oncol. 2020, 43, 631-641. [CrossRef]

122. Zhang, D.-L.; Qu, L.-W.; Ma, L.; Zhou, Y.-C.; Wang, G.-Z.; Zhao, X.-C.; Zhang, C.; Zhang, Y.-F.; Wang, M.; Zhang, M.-Y.; et al. Genome-wide identification of transcription factors that are critical to non-small cell lung cancer. Cancer Lett. 2018, 434, 132-143. [CrossRef]

123. Gautam, A.K.; Wang, C.; Zeng, J.; Wang, J.; Lu, J.; Wei, J.; Huang, G.; Mo, B.; Luo, M.; Mo, B. Expression and clinical significance of SALL4 and LGR5 in patients with lung cancer. Oncol. Lett. 2015, 10, 3629-3634. [CrossRef]

124. Yanagihara, N.; Kobayashi, D.; Kuribayashi, K.; Tanaka, M.; Hasegawa, T.; Watanabe, N. Significance of SALL4 as a drug-resistant factor in lung cancer. Int. J. Oncol. 2015, 46, 1527-1534. [CrossRef]

125. Abnet, C.C.; Arnold, M.; Wei, W.-Q. Epidemiology of Esophageal Squamous Cell Carcinoma. Gastroenterology 2018, 154, 360-373. [CrossRef] 
126. Forghanifard, M.M.; Khales, S.A.; Javdani-Mallak, A.; Rad, A.; Farshchian, M.; Abbaszadegan, M.R. Stemness state regulators SALL4 and SOX2 are involved in progression and invasiveness of esophageal squamous cell carcinoma. Med. Oncol. 2014, 31, 1-8. [CrossRef]

127. Yu, J.; Zhu, T.; Wang, Z.; Zhang, H.; Qian, Z.; Xu, H.; Gao, B.; Wang, W.; Gu, L.; Meng, J.; et al. A Novel Set of DNA Methylation Markers in Urine Sediments for Sensitive/Specific Detection of Bladder Cancer. Clin. Cancer Res. 2007, 13, 7296-7304. [CrossRef]

128. Van Der Heijden, A.G.; Mengual, L.; Ingelmo, M.; Lozano, J.J.; Westerlo, C.C.M.V.R.-V.D.; Baixauli, M.; Geavlete, B.; Moldoveanud, C.; Ene, C.; Dinney, C.P.; et al. Urine cell-based DNA methylation classifier for monitoring bladder cancer. Clin. Epigenet. 2018, 10, 71. [CrossRef]

129. Cao, D.; Humphrey, P.A.; Allan, R.W. SALL4 is a novel sensitive and specific marker for metastatic germ cell tumors, with particular utility in detection of metastatic yolk sac tumors. Cancer 2009, 115, 2640-2651. [CrossRef]

130. Ma, Y.; Singer, D.B.; Gozman, A.; Ford, D.; Chai, L.; Steinhoff, M.M.; Hansen, K.; Maizel, A.L. Hsal 1 is related to kidney and gonad development and is expressed in Wilms tumor. Pediatr. Nephrol. 2001, 16, 701-709. [CrossRef]

131. Brown, K.W.; Charles, A.; Dallosso, A.; White, G.; Charlet, J.; Standen, G.R.; Malik, K. Characterization of 17.94, a novel anaplastic Wilms' tumor cell line. Cancer Genet. 2012, 205, 319-326. [CrossRef]

132. Li, C.-M.; Guo, M.; Borczuk, A.; Powell, C.A.; Wei, M.; Thaker, H.M.; Friedman, R.; Klein, U.; Tycko, B. Gene Expression in Wilms' Tumor Mimics the Earliest Committed Stage in the Metanephric Mesenchymal-Epithelial Transition. Am. J. Pathol. 2002, 160, 2181-2190. [CrossRef]

133. Artemov, A.V.; Zhigalova, N.; Zhenilo, S.; Mazur, A.M.; Prokhortchouk, E.B. VHL inactivation without hypoxia is sufficient to achieve genome hypermethylation. Sci. Rep. 2018, 8, 10667. [CrossRef]

134. Deisch, J.; Raisanen, J.; Rakheja, D. Immunoexpression of SALL4 in Wilms Tumors and Developing Kidney. Pathol. Oncol. Res. 2011, 17, 639-644. [CrossRef]

135. Harbeck, N.; Penault-Llorca, F.; Cortes, J.; Gnant, M.; Houssami, N.; Poortmans, P.; Ruddy, K.; Tsang, J.; Cardoso, F. Breast cancer. Nat. Rev. Dis. Primers 2019, 5, 66. [CrossRef]

136. Liu, L.-Y.; Chang, L.-Y.; Kuo, W.-H.; Hwa, H.-L.; Chang, K.-J.; Hsieh, F.-J. A Supervised Network Analysis on Gene Expression Profiles of Breast Tumors Predicts a 41-Gene Prognostic Signature of the Transcription FactorMYBacross Molecular Subtypes. Comput. Math. Methods Med. 2014, 2014, 1-19. [CrossRef]

137. Zuo, Y.; Cui, Y.; Yu, G.; Li, R.; Ressom, H.W. Incorporating prior biological knowledge for network-based differential gene expression analysis using differentially weighted graphical LASSO. BMC Bioinform. 2017, 18, 1-14. [CrossRef] [PubMed]

138. Wolf, J.; Müller-Decker, K.; Flechtenmacher, C.; Zhang, F.; Shahmoradgoli, M.; Mills, G.B.; Hoheisel, J.D.; Boettcher, M. An in vivo RNAi screen identifies SALL1 as a tumor suppressor in human breast cancer with a role in CDH1 regulation. Oncogene 2014, 33, 4273-4278. [CrossRef] [PubMed]

139. Watanabe; Kobayashi, D.; Kuribayshi, K.; Tanaka, M. SALL4 is essential for cancer cell proliferation and is overexpressed at early clinical stages in breast cancer. Int. J. Oncol. 2011, 38, 933-939. [CrossRef]

140. Itou, J.; Matsumoto, Y.; Yoshikawa, K.; Toi, M. Sal-like 4(SALL4) suppressesCDH1expression and maintains cell dispersion in basal-like breast cancer. FEBS Lett. 2013, 587, 3115-3121. [CrossRef]

141. Itou, J.; Tanaka, S.; Li, W.; Iida, A.; Sehara-Fujisawa, A.; Sato, F.; Toi, M. The Sal-like 4-Integrin $\alpha 6 \beta 1$ network promotes cell migration for metastasis via activation of focal adhesion dynamics in basal-like breast cancer cells. Biochim. Biophys. Acta (BBA)-Bioenerg. 2017, 1864, 76-88. [CrossRef]

142. Chen, T.; Tsang, J.Y.S.; Su, X.; Li, P.; Sun, W.; Wong, I.L.K.; Choy, K.; Yang, Q.; Tse, G.M.K.; Chan, T.H.; et al. SALL4 promotes tumor progression in breast cancer by targeting EMT. Mol. Carcinog. 2020, 59, 1209-1226. [CrossRef] [PubMed]

143. Dirican, E.; Akkiprik, M. Functional and clinical significance of SALL4 in breast cancer. Tumor Biol. 2016, 37, 11701-11709. [CrossRef]

144. Hanif, F.; Muzaffar, K.; Perveen, K.; Malhi, S.M.; Simjee, S.U. Glioblastoma Multiforme: A Review of its Epidemiology and Pathogenesis through Clinical Presentation and Treatment. Asian Pac. J. Cancer Prev. 2017, 18, 3-9.

145. Sung, C.K.; Li, D.; Andrews, E.; Drapkin, R.; Benjamin, T. Promoter methylation of the SALL2 tumor suppressor gene in ovarian cancers. Mol. Oncol. 2012, 7, 419-427. [CrossRef]

146. Parroche, P.; Touka, M.; Mansour, M.; Bouvard, V.; Thépot, A.; Accardi, R.; Carreira, C.; Roblot, G.G.; Sylla, B.S.; Hasan, U.; et al. Human papillomavirus type 16 E6 inhibits p21WAF1 transcription independently of p53 by inactivating p150Sal2. Virology 2011, 417, 443-448. [CrossRef]

147. Yu, D.; Khan, O.F.; Suvà, M.L.; Dong, B.; Panek, W.K.; Xiao, T.; Wu, M.; Han, Y.; Ahmed, A.U.; Balyasnikova, I.V.; et al. Multiplexed RNAi therapy against brain tumor-initiating cells via lipopolymeric nanoparticle infusion delays glioblastoma progression. Proc. Natl. Acad. Sci. USA 2017, 114, E6147-E6156. [CrossRef]

148. Zhang, L.; Yan, Y.; Jiang, Y.; Cui, Y.; Zou, Y.; Qian, J.; Luo, C.; Lu, Y.; Wu, X. The expression of SALL4 in patients with gliomas: High level of SALL4 expression is correlated with poor outcome. J. Neuro-Oncol. 2014, 121, 261-268. [CrossRef]

149. Chi, D.; Zhang, W.; Jia, Y.; Cong, D.; Hu, S. Spalt-Like Transcription Factor 1 (SALL1) Gene Expression Inhibits Cell Proliferation and Cell Migration of Human Glioma Cells Through the Wnt/ $\beta$-Catenin Signaling Pathway. Med. Sci. Monit. Basic Res. 2019, 25, 128-138. [CrossRef]

150. Hu, D.; Shilatifard, A. Epigenetics of hematopoiesis and hematological malignancies. Genes Dev. 2016, 30, 2021-2041. [CrossRef] 
151. Tong, W.-G.; Wierda, W.G.; Lin, E.; Kuang, S.-Q.; Bekele, B.N.; Estrov, Z.; Wei, Y.; Yang, H.; Keating, M.J.; Garcia-Manero, G. Genome-wide DNA methylation profiling of chronic lymphocytic leukemia allows identification of epigenetically repressed molecular pathways with clinical impact. Epigenetics 2010, 5, 499-508. [CrossRef]

152. Kuang, S.-Q.; Tong, W.-G.; Yang, H.; Lin, W.; Lee, M.K.; Fang, Z.H.; Wei, Y.; Jelinek, J.; Issa, J.-P.; Garcia-Manero, G. Genome-wide identification of aberrantly methylated promoter associated CpG islands in acute lymphocytic leukemia. Leukemia 2008, 22, 1529-1538. [CrossRef]

153. Yang, J. SALL4 as a transcriptional and epigenetic regulator in normal and leukemic hematopoiesis. Biomark. Res. 2018, 6, 1-9. [CrossRef] [PubMed]

154. Shuai, X.; Zhou, D.; Shen, T.; Wu, Y.; Zhang, J.; Wang, X.; Li, Q. Overexpression of the novel oncogene SALL4 and activation of the Wnt/ $\beta$-catenin pathway in myelodysplastic syndromes. Cancer Genet. Cytogenet. 2009, 194, 119-124. [CrossRef]

155. Gao, C.; Dimitrov, T.; Yong, K.J.; Tatetsu, H.; Jeong, H.-W.; Luo, H.R.; Bradner, J.E.; Tenen, D.; Chai, L. Targeting transcription factor SALL4 in acute myeloid leukemia by interrupting its interaction with an epigenetic complex. Blood 2013, 121, 1413-1421. [CrossRef]

156. Dekker, E.; Tanis, P.J.; Vleugels, J.L.A.; Kasi, P.M.; Wallace, M.B. Colorectal cancer. Lancet 2019, 394, 1467-1480. [CrossRef]

157. Zhang, C.; Zhao, H.; Li, J.; Liu, H.; Wang, F.; Wei, Y.; Su, J.; Zhang, N.; Liu, T.; Zhang, Y. The Identification of Specific Methylation Patterns across Different Cancers. PLoS ONE 2015, 10, e0120361. [CrossRef]

158. Zheng, W.; Lu, Y.; Feng, X.; Yang, C.; Qiu, L.; Deng, H.; Xue, Q.; Sun, K. Improving the overall survival prognosis prediction accuracy: A 9-gene signature in CRC patients. Cancer Med. 2021, 10, 5998-6009. [CrossRef]

159. Forghanifard, M.M.; Moghbeli, M.; Raeisossadati, R.; Tavassoli, A.; Mallak, A.J.; Boroumand-Noughabi, S.; Abbaszadegan, M.R. Role of SALL4 in the progression and metastasis of colorectal cancer. J. Biomed. Sci. 2013, 20, 6. [CrossRef]

160. Cheng, J.; Deng, R.; Wu, C.; Zhang, P.; Wu, K.; Shi, L.; Liu, X.; Bai, J.; Deng, M.; Gao, J.; et al. Inhibition of SALL4 suppresses carcinogenesis of colorectal cancer via regulating Gli1 expression. Int. J. Clin. Exp. Pathol. 2015, 8, 10092-10101.

161. Wu, H.-K.; Liu, C.; Fan, X.-X.; Wang, H.; Zhou, L. Spalt-like transcription factor 4 as a potential diagnostic and prognostic marker of colorectal cancer. Cancer Biomark. 2017, 20, 191-198. [CrossRef] [PubMed]

162. Hao, L.; Zhao, Y.; Wang, Z.; Yin, H.; Zhang, X.; He, T.; Song, S.; Sun, S.; Wang, B.; Li, Z.; et al. Expression and clinical significance of SALL4 and $\beta$-catenin in colorectal cancer. J. Mol. Histol. 2016, 47, 117-128. [CrossRef] [PubMed]

163. Bahadori, M.; Baharara, J.; Amini, E. Anticancer Properties of Chrysin on Colon Cancer Cells, In vitro and In vivo with Modulation of Caspase-3, -9, Bax and Sall4. Iran. J. Biotechnol. 2016, 14, 177-184. [CrossRef]

164. Ma, T.; Shi, S.; Jiang, H.; Chen, X.; Xu, D.; Ding, X.; Zhang, H.; Xi, Y. A pan-cancer study of spalt-like transcription factors $1 / 2 / 3 / 4$ as therapeutic targets. Arch. Biochem. Biophys. 2021, 711, 109016. [CrossRef]

165. Kim, S.; Park, S.; Lee, J.; Park, Y.; Kim, H. 201 Transcriptome analysis of CD133-positive stem cells and prognostic value of survivin in colorectal cancer. Eur. J. Cancer 2014, 50, 65. [CrossRef]

166. Zhang, C.; Huang, C.; Sui, X.; Zhong, X.; Yang, W.; Hu, X.; Li, Y. Association between gene methylation and HBV infection in hepatocellular carcinoma: A meta-analysis. J. Cancer 2019, 10, 6457-6465. [CrossRef] [PubMed]

167. Shikauchi, Y.; Saiura, A.; Kubo, T.; Niwa, Y.; Yamamoto, J.; Murase, Y.; Yoshikawa, H. SALL3 Interacts with DNMT3A and Shows the Ability To Inhibit CpG Island Methylation in Hepatocellular Carcinoma. Mol. Cell. Biol. 2009, 29, 1944-1958. [CrossRef]

168. Yang, X.-X.; Sun, J.-Z.; Li, F.-X.; Wu, Y.-S.; Du, H.-Y.; Zhu, W.; Li, X.-H.; Li, M. Aberrant methylation and downregulation ofsall3in human hepatocellular carcinoma. World J. Gastroenterol. 2012, 18, 2719-2726. [CrossRef]

169. Jee, B.A.; Choi, J.-H.; Rhee, H.; Yoon, S.; Kwon, S.M.; Nahm, J.H.; Yoo, J.E.; Jeon, Y.; Choi, G.H.; Woo, H.G.; et al. Dynamics of Genomic, Epigenomic, and Transcriptomic Aberrations during Stepwise Hepatocarcinogenesis. Cancer Res. 2019, 79, 5500-5512. [CrossRef] [PubMed]

170. Fan, H.; Cui, Z.; Zhang, H.; Mani, S.K.K.; Diab, A.; Lefrancois, L.; Fares, N.; Merle, P.; Andrisani, O. DNA demethylation induces SALL4 gene re-expression in subgroups of hepatocellular carcinoma associated with Hepatitis B or C virus infection. Oncogene 2016, 36, 2435-2445. [CrossRef]

171. Oikawa, T.; Kamiya, A.; Zeniya, M.; Chikada, H.; Hyuck, A.D.; Yamazaki, Y.; Wauthier, E.; Tajiri, H.; Miller, L.; Wang, X.W.; et al. Sal-like protein 4 (SALL4), a stem cell biomarker in liver cancers. Hepatology 2013, 57, 1469-1483. [CrossRef]

172. Yin, F.; Han, X.; Yao, S.-K.; Wang, X.-L.; Yang, H.-C. Importance of SALL4 in the development and prognosis of hepatocellular carcinoma. World J. Gastroenterol. 2016, 22, 2837-2843. [CrossRef]

173. Zeng, S.S.; Yamashita, T.; Kondo, M.; Nio, K.; Hayashi, T.; Hara, Y.; Nomura, Y.; Yoshida, M.; Hayashi, T.; Oishi, N.; et al. The transcription factor SALL4 regulates stemness of EpCAM-positive hepatocellular carcinoma. J. Hepatol. 2014, 60, 127-134. [CrossRef]

174. Yong, K.J.; Gao, C.; Lim, J.S.; Yan, B.; Yang, H.; Dimitrov, T.; Kawasaki, A.; Ong, C.W.; Wong, K.-F.; Lee, S.; et al. Oncofetal Gene SALL4 in Aggressive Hepatocellular Carcinoma. N. Engl. J. Med. 2013, 368, 2266-2276. [CrossRef]

175. Sideras, K.; Bots, S.J.; Biermann, K.; Sprengers, D.; Polak, W.G.; Ijzermans, J.N.M.; de Man, R.A.; Pan, Q.; Sleijfer, S.; Bruno, M.J.; et al. Tumour antigen expression in hepatocellular carcinoma in a low-endemic western area. Br. J. Cancer 2015, 112, 1911-1920. [CrossRef]

176. Wang, J.; Huang, J.; Ma, Q.; Liu, G. Association between quantitative parameters of CEUS and Sall4/Wnt/ $\beta$-catenin signaling in patients with hepatocellular carcinoma. Cancer Manag. Res. 2019, 11, 3339-3347. [CrossRef] 
177. Zhao, B.; Wang, Y.; Tan, X.; Ke, K.; Zheng, X.; Wang, F.; Lan, S.; Liao, N.; Cai, Z.; Shi, Y.; et al. Inflammatory Micro-environment Contributes to Stemness Properties and Metastatic Potential of HCC via the NF-kB/miR-497/SALL4 Axis. Mol. Ther.-Oncolytics 2019, 15, 79-90. [CrossRef]

178. Yin, C.; Han, Q.; Xu, D.; Zheng, B.; Zhao, X.; Zhang, J. SALL4-mediated upregulation of exosomal miR-146a-5p drives T-cell exhaustion by M2 tumor-associated macrophages in HCC. OncoImmunology 2019, 8, e1601479. [CrossRef]

179. Cheng, Y.; He, C.; Wang, M.; Ma, X.; Mo, F.; Yang, S.; Han, J.; Wei, X. Targeting epigenetic regulators for cancer therapy: Mechanisms and advances in clinical trials. Signal Transduct. Target. Ther. 2019, 4, 62. [CrossRef] [PubMed]

180. Boda, D.; Docea, A.O.; Calina, D.; Ilie, M.A.; Caruntu, C.; Zurac, S.; Neagu, M.; Constantin, C.; Branisteanu, D.E.; Voiculescu, V.; et al. Human papilloma virus: Apprehending the link with carcinogenesis and unveiling new research avenues (Review). Int. J. Oncol. 2018, 52, 637-655. [CrossRef]

181. Wei, X.; Zhang, S.; Cao, D.; Zhao, M.; Zhang, Q.; Zhao, J.; Yang, T.; Pei, M.; Wang, L.; Li, Y.; et al. Aberrant Hypermethylation of SALL3 with HPV Involvement Contributes to the Carcinogenesis of Cervical Cancer. PLoS ONE 2015, 10, e0145700. [CrossRef]

182. Yong, K.J.; Li, A.; Ou, W.-B.; Hong, C.K.Y.; Zhao, W.; Wang, F.; Tatetsu, H.; Yan, B.; Qi, L.; Fletcher, J.A.; et al. Targeting SALL4 by entinostat in lung cancer. Oncotarget 2016, 7, 75425-75440. [CrossRef]

183. Liu, B.H.; Jobichen, C.; Chia, C.S.B.; Chan, T.H.M.; Tang, J.P.; Chung, T.X.Y.; Li, J.; Poulsen, A.; Hung, A.W.; Koh-Stenta, C.X.; et al. Targeting cancer addiction for SALL4 by shifting its transcriptome with a pharmacologic peptide. Proc. Natl. Acad. Sci. USA 2018, 115, E7119-E7128. [CrossRef]

184. Sievers, Q.L.; Petzold, G.; Bunker, R.D.; Renneville, A.; Słabicki, M.; Liddicoat, B.J.; Abdulrahman, W.; Mikkelsen, T.; Ebert, B.L.; Thomä, N.H. Defining the human C2H2 zinc finger degrome targeted by thalidomide analogs through CRBN. Science 2018, 362, eaat0572. [CrossRef]

185. Donovan, K.A.; An, J.; Nowak, R.P.; Yuan, J.C.; Fink, E.C.; Berry, B.C.; Ebert, B.L.; Fischer, E.S. Thalidomide promotes degradation of SALL4, a transcription factor implicated in Duane Radial Ray syndrome. eLife 2018, 7, 1-25. [CrossRef]

186. Akiyama, R.; Kawakami, H.; Wong, J.; Oishi, I.; Nishinakamura, R.; Kawakami, Y. Sall4-Gli3 system in early limb progenitors is essential for the development of limb skeletal elements. Proc. Natl. Acad. Sci. USA 2015, 112, 5075-5080. [CrossRef]

187. Chen, K.Q.; Tahara, N.; Anderson, A.; Kawakami, H.; Kawakami, S.; Nishinakamura, R.; Pandolfi, P.P.; Kawakami, Y. Development of the Proximal-Anterior Skeletal Elements in the Mouse Hindlimb Is Regulated by a Transcriptional and Signaling Network Controlled by Sall4. Genetics 2020, 215, 129-141. [CrossRef]

188. Shen, L.; Shi, Q.; Wang, W. Double agents: Genes with both oncogenic and tumor-suppressor functions. Oncogenesis 2018, 7, 1-14. [CrossRef]

189. Kishibuchi, R.; Kondo, K.; Soejima, S.; Tsuboi, M.; Kajiura, K.; Kawakami, Y.; Kawakita, N.; Sawada, T.; Toba, H.; Yoshida, M.; et al. DNA methylation of GHSR, GNG4, HOXD9 and SALL3 is a common epigenetic alteration in thymic carcinoma. Int. J. Oncol. 2019, 56, 315-326. [CrossRef] 